\title{
New Donor Functionalized Cp Ligands: Synthesis and Complexation Behaviour of Quinoxalyl and Benzothiadiazolyl Systems
}

\begin{tabular}{|c|c|}
\hline Journal: & Zeitschrift für Anorganische und Allgemeine Chemie \\
\hline Manuscript ID: & zaac. $200900100 . R 2$ \\
\hline Wiley - Manuscript type: & Article \\
\hline $\begin{array}{l}\text { Date Submitted by the } \\
\text { Author: }\end{array}$ & 08-Apr-2009 \\
\hline Complete List of Authors: & $\begin{array}{l}\text { Enders, Markus; Ruprecht-Karls-Universität Heidelberg, } \\
\text { Anorganisch Chemisches Institut } \\
\text { Wadepohl, Hubert } \\
\text { Schuhen, Katrin } \\
\text { Sieb, David }\end{array}$ \\
\hline Keywords: & $\begin{array}{l}\text { Donor functionalized Cp ligands, Benzothiadiazole, Ferrocene, } \\
\text { Chromium, Olefin Polymerization }\end{array}$ \\
\hline
\end{tabular}

\section{S ScholaroNE" \\ Manuscript Central}




\title{
New Donor Functionalized Cp Ligands: Synthesis and Complexation Behaviour of Quinoxalyl and Benzothiadiazolyl Systems
}

\author{
Katrin Schuhen, ${ }^{[\mathrm{a}]}$ David Sieb $^{[\mathrm{a}]}$, Hubert Wadepohl ${ }^{[\mathrm{a}]}$ and Markus Enders ${ }^{*[\mathrm{a}]}$
}

Keywords: Donor functionalized Cp ligands, Benzothiadiazole, Quinoxaline, Ferrocene, paramagnetic NMR, Olefin Polymerization

Sodium cyclopentadienide reacts as nucleophile with 4,7-dibromo2,1,3-benzothiadiazole (BTZ) and leads to the new donorfunctionalized ligand $\mathrm{Cp}^{\mathrm{BTZ}}$. Related quinoxalyl $\mathrm{Cp}$-systems have been prepared using Pd-catalyzed coupling with zincated $\mathrm{Cp}$-metal complexes. The new ligands comprise two N-donor atoms; one of them is located in a distal position relative to the metal centre so that it cannot coordinate in a chelating manner..
With $\mathrm{Cp}^{\mathrm{BTZ}}$ ligand derivatives several metal complexes have been synthesized The new chromium(III) complex $\mathrm{Cp}^{\mathrm{BTZ}} \mathrm{CrCl}_{2}$ (12) becomes upon activation an active catalyst for the polymerization of ethylene. Relying on DFT-calculations and analysis of spin-density distribution combined with paramagnetic NMR-data a chelating coordination of the $\mathrm{Cp}^{\mathrm{BTZ}}$ ligand is feasible in $\mathbf{1 2}$.
[a] Anorganisch-Chemisches Institut der Ruprecht-Karls-Universität Heidelberg, Im Neuenheimer Feld 270, D-69120 Heidelberg, GERMANY
Fax: +49(0)6221 541616247
E-mail: markus.enders@uni-hd.de

\section{INTRODUCTION}

The attachment of neutral donor functions to cyclopentadienes via suitable spacers leads to monoanionic chelating ligands where the steric and electronic properties of cyclopentadienyl ligands are considerably modulated. Therefore a large number of such ligands have been developed ${ }^{1}$ and the resulting metal complexes served as active catalysts for the polymerization ${ }^{2}$ and oligomerization ${ }^{3}$ of olefins, for $\mathrm{CH}$-activation ${ }^{4}$ or hydroamination of alkynes ${ }^{5}$. The role of the donor group is the completion of the coordination sphere of the metal in a predefined geometry and to modulate the metal reactivity. Additionally, ligands have been developed where for steric reasons the attached donor group cannot coordinate to the $\mathrm{Cp}$ bound metal atom. ${ }^{6}$ We now report the synthesis of a new type of donor functionalized $\mathrm{Cp}$ ligands where one donor atom is able to coordinate to the $\mathrm{Cp}$ bound metal atom and a second donor function remains uncoordinated so that additional metal atoms or Lewis acids can bind. Such interactions could lead to a modulation of the properties of catalysts (e.g. Al-alkyls in olefin polymerization catalysts). The two donor atoms are incorporated into a heteroaromatic ring which enables electronic communication. We have chosen 2,1,3-benzothiadiazole and quinoxaline respectively as pendant groups attached to the $\mathrm{Cp}$ rings. This leads to a rigid arrangement of the new ligands with a $\mathrm{C}_{2}$ spacer between the chelating donor atom and the $\mathrm{Cp}$ ring.

\section{RESULTS AND DISCUSSION}

Synthesis of Cp-ligands with a pendant 2,1,3-benzothiadiazole

Benzene derivatives usually do not react with cyclopentadienides as nucleophiles except when they are substituted with strongly electron withdrawing groups. ${ }^{1 \mathrm{~h}, 7}$ In benzothiadiazoles the homocyclic ring is also activated for the reaction with nucleophiles which can be explained by the contribution of several mesomeric resonance structures (see scheme 1). ${ }^{8}$ Therefore we treated 4,7dibromo-2,1,3-benzothiadiazole with lithium indenide (Li-Ind) and after hydrolysis we obtained the donor functionalized indene H1 as a single isomer. The yield of the reaction increases considerably to $90 \%$ when two equivalents of lithium indenide are used, as the initially formed product is quickly deprotonated by Li-Ind under formation of the intensely colored anion 1: The structure of H1 was established by X-Ray diffraction analysis of a twinned crystal. The four independent molecules found in the asymmetric unit only differ by the relative arrangement of the two ring systems with respect to torsion around the connecting carbon carbon bond (torsion angles $-42.6,-43.7,39.3$ and $43.0^{\circ}$ ). The distances C1-C2, C1-C6 and C5-C6 are with $1.42-1.44 \AA$ considerably longer than the other $\mathrm{C}-\mathrm{C}$ distances in the benzothiadiazole moiety which indicates an important contribution of the mesomeric structure B (scheme 1).
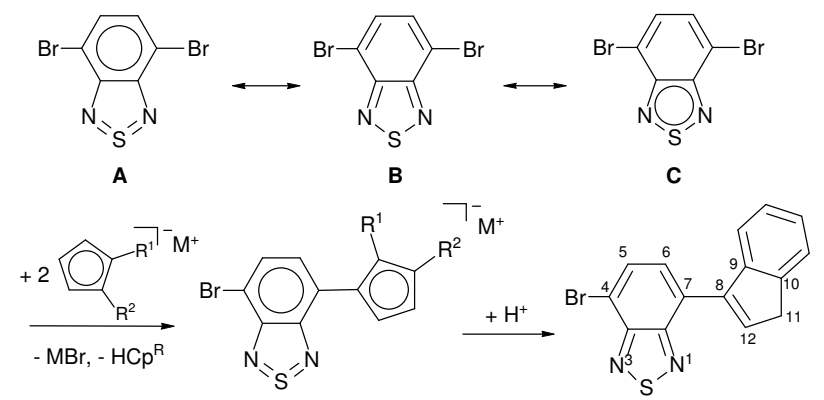

$\begin{aligned} & R^{1} / R^{2}=\text { benzo: } 1 \mathrm{Li} \\ & R^{1}=R^{2}=H: 2 N a\end{aligned}$

$\mathrm{H1}$ $R^{1}=H, R^{2}=t-B u: 3 L i$<smiles>Brc1ccc(C2=CC=CC2)c2nsnc12</smiles>

$\mathrm{H} 2$<smiles></smiles> 
Scheme 1: Mesomeric resonance structures of benzothiadiazole $(\mathbf{A}-\mathbf{C})$ and formation of cyclopentadienes functionalized with 2,1,3 benzothiadiazole. (Numbering of atoms for NMR assignment in exp. part).

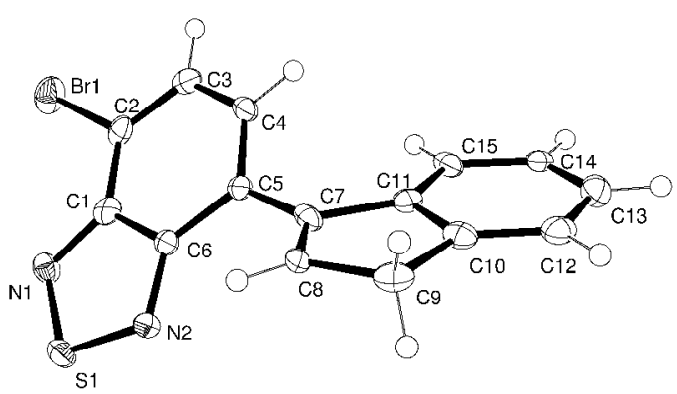

Figure 1. Solid-state molecular structure of one of four independent molecules of H1. Selected bond lengths $[\AA]$ and angles $\left[{ }^{\circ}\right]$ : C1-N1 1.347(5), N1-S1 1.617(3), S1-N2 1.611(3), N2-C6 1.357(5), C1-C2 1.418(5), C2-C3 1.365(5), C3-C4 1.396(5), C4-C5 1.367(5), C5-C6 1.437(5), C6-C1 1.444(5), C5-C7 1.464(5), C6-N2-S1 106.2(3), N2-S1-N1 101.5(2), S1-N1C1 106.3(2), C6-C5-C7-C8 -43.7(6).

The synthesis of $\mathrm{H} \mathbf{1}$ shows that lithium indenide is sufficiently reactive for the nucleophilic substitution of bromide in dibromobenzothiadiazole. Compared to lithium indenide, alkaline metal cyclopentadienides are less nucleophilic. Nevertheless the reaction with $\mathrm{NaC}_{5} \mathrm{H}_{5}$ leads to the formation of $2 \mathrm{Na}$. After aqueous workup the product could be identified by GC-MS analysis, but it was not possible to isolate the cyclopentadiene H2. The low stability of $\mathrm{H} 2$ is in accordance with similar properties of 8quinolylcyclopentadiene. ${ }^{9}$ The stability of functionalized cyclopentadienes increases with additional alkyl substituents. Therefore we tried to synthesize the corresponding tetramethyl derivative. However, the unsubstituted carbon atom in lithium tetramethylcyclopentadienide is less nucleophilic compared to the neighboring C-atoms which carry a methyl substituent. Consequently the reaction occurs at a position which is already substituted so that a cyclopentadiene is formed which cannot be deprotonated and hence is no longer useful as ligand (scheme 2).<smiles>Brc1ccc(Br)c2nsnc12</smiles><smiles></smiles>

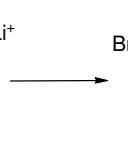<smiles>CC1=CC(C)(c2ccc(Br)c3nsnc23)C(C)=C1C</smiles>

Scheme 2. Formation of the "wrong" isomer 4.

By increasing the steric bulk at the cyclopentadiene substituent a second substitution at this position can be prevented. Therefore lithium $t$-butylcyclopentadienide was used leading to the isomers H3a and H3b (see scheme 1).

We also tried to attach a second cyclopentadiene to compound $\mathbf{3}$ by reaction of dibromobenzothiadiazole with an excess of $t$-butylcyclopentadienide, but this reaction was not successful. However, such a ligand system can be obtained by Negishi-type Pd catalyzed coupling of zincated Cp-metal complexes. Both, mono-zincated and bis-zincated ferrocene react with one equivalent of 4,7dibromobenzothiadiazole in the presence of a $\operatorname{Pd}(0)$ catalyst under formation of compound 5. When an excess of the zincated ferrocene is used, the bimetallic compound $\mathbf{6}$ is obtained (see scheme 3). The ferrocene units in $\mathbf{6}$ communicate electronically through the benzothiadiazole unit which is expressed by a peak separation of $100 \mathrm{mV}$ in the cyclic voltammogram. ${ }^{10}$
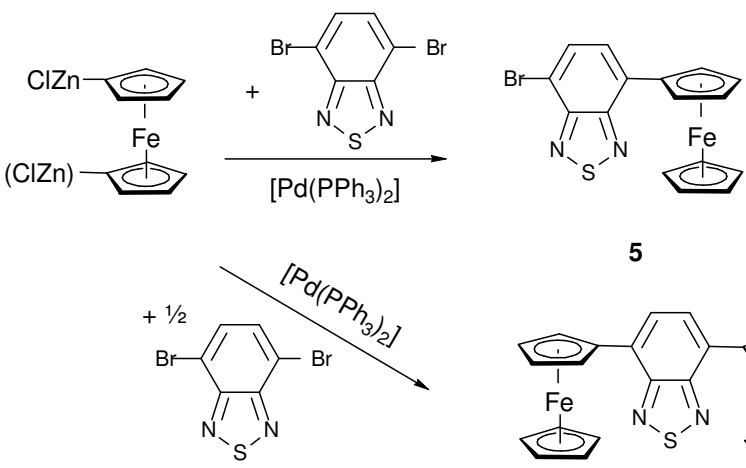

5

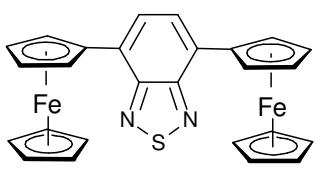

Scheme 3. Formation of mono- and bis-ferrocenyl benzothiadiazoles

We also envisaged synthesizing ligands where a quinoxaline unit is attached to a cyclopentadiene. This could lead to metal complexes with a similar geometry as 8-quinoline metal complexes. The latter compounds have been extensively studied by us and some of them showed interesting catalytic behaviour. ${ }^{2 \mathrm{~d}, 4}$ However, the homocyclic part of quinoxaline is not sufficiently activated for nucleophilic substitution so that the Pd-catalyzed reaction with zincated Cp-metal complexes had to be employed. The complexes $\mathbf{7}$ and $\mathbf{8}$ have been obtained in good yields and the solid state molecular structures have been determined. Figure 2 and figure 3 show the relative orientation of the nearly planar quinoxaline units to the $\mathrm{Cp}$ rings. In $\mathbf{7}$ the metals are in a trans-arrangement whereas in $\mathbf{8}$ they are cis-oriented. In both compounds the heterocycles and the $\mathrm{Cp}$ rings form angles of approximately $25^{\circ}$. This small angle allows electronic communication between the metal centres which is expressed in the cyclic voltammogram. 7 shows a peak separation of the two oxidation potentials of $80 \mathrm{mV}$, a value which is somewhat smaller compared to the benzothiadiazole bridged ferrocene 6.<smiles>CC(=[Mg])c1ccccc1</smiles><smiles>Brc1ccc(Br)c2nccnc12</smiles>
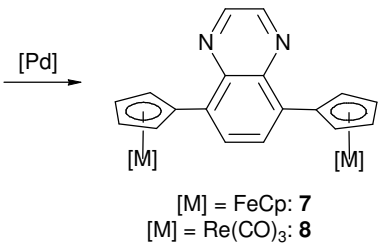

Scheme 4. Formation of quinoxalyl bridged complexes $\mathbf{7}$ and $\mathbf{8}$.

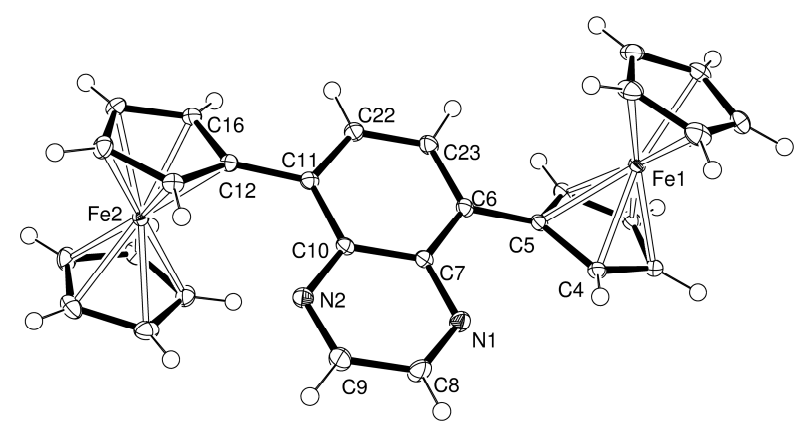

Figure 2. Solid state molecular structures of 7. Selected bond lengths $[\AA]$ and angles [ ${ }^{\circ}$ ]: C5-C6 1.478(2), C6-C7 1.429(3), C7-N1 1.357(2), N1-C8 1.318(3), C8-C9 1.406(3), C9-N2 1.321(3), N2-C10 1.368(2), C10-C11 
1.431(3), C11-C22 1.381(3), C22-C23 1.404(3), C23-C6 1.384(3), C4-C5C6-C7 -24.8(3), C22-C11-C12-C16 25.2(3).

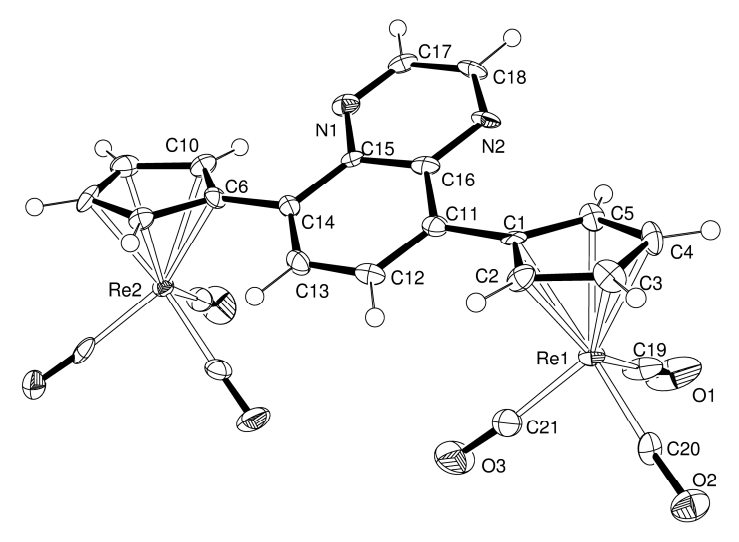

Figure 3. Solid state molecular structures of $\mathbf{8}$. Selected angles [ ${ }^{\circ}$ ]: C2-C1C11-C12 -23.2(14), C7-C6-C14-C13 24.6(15).

\section{Complexation of ligands 1 - 3}

The ligands $\mathbf{1}$ and $\mathbf{3}$ can be introduced easily into metal complexes, as the protonated ligands are readily available. Two examples with ligand precursor $\mathrm{H} \mathbf{1}$ are presented in scheme 5 . Deprotonation of $\mathrm{H1}$ with potassium hydride leads to the indenide derivative $\mathrm{K} 1$ which was reacted with $\left[\mathrm{ClRh}\left(\mathrm{C}_{2} \mathrm{H}_{4}\right)_{2}\right]_{2}$. The resulting rhodium(I) bis-ethene complex $\mathbf{1 0}$ was isolated in $45 \%$ yield. As the $\mathrm{Rh}$ atom is coordinatively saturated, no $\mathrm{N}-\mathrm{Rh}$ interaction is possible. Therefore we tried to remove one $\mathrm{C}_{2} \mathrm{H}_{4}$ by irradiation with visible light. With the related quinolyl complexes we were able to identify $\mathrm{N}$-donor stabilized $\mathrm{Rh}(\mathrm{I})$ mono-ethene complexes which showed activity in catalytic H/D exchange reactions. ${ }^{4}$ The irradiation of $\mathbf{1 0}$ also leads to ethene elimination, but unfortunately the reaction is not selective and no products could be identified. The zirconium complex 9 was obtained in a clean reaction between $\mathrm{H} 1$ and $\mathrm{Zr}(\mathrm{NMe}){ }_{4} \cdot{ }^{15} \mathrm{~N}$ NMR demonstrates that there is no coordination of the benzothiadiazole to the $\mathrm{Zr}$ atom, as the chemical shifts of the two $\mathrm{N}$-atoms are very similar $(\delta=$ $333.7,336.6 \mathrm{ppm})$ and almost equal to the ${ }^{15} \mathrm{~N}$ shifts of $\mathrm{H} 1$ (335.8, $338.6 \mathrm{ppm})$. This is in contrast to a related indenyl $\mathrm{Zr}\left(\mathrm{NMe}_{2}\right)_{3}$ complex where a pendant pyridyl coordinates to the $\mathrm{Zr}$-atom. However, a relatively long $\mathrm{Zr}$-N-distance indicates that this interaction is weak. ${ }^{11}$ Thus it is not unexpected that the pendant donor in 9 does not bind to $\mathrm{Zr}$.<smiles></smiles><smiles></smiles><smiles>CN(C)[Ge](C)(C)c1ccccc1-c1ccc(Br)c2nsnc12</smiles>

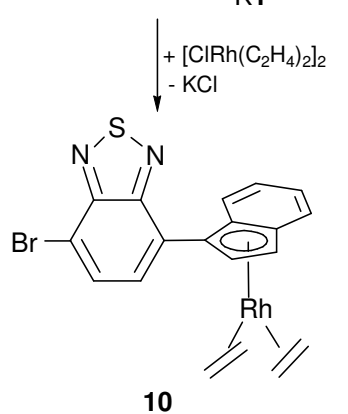

Scheme 5. Complexation of ligand $\mathbf{1}$.

Deprotonation of the two isomers H3a and H3b with potassium hydride results in the formation of the intensely blue colored anion $\mathrm{K} 3$ which shows an absorption maximum in the visible region at $675 \mathrm{~nm}(\varepsilon=5400)$. Subsequent reaction with $\mathrm{FeCl}_{2}$ yields the ferrocene derivative $\mathbf{1 1}$ as a blue solid (scheme 6). Due to the unsymmetric 1,3-disubstitution at the Cp-rings, a 1:1 mixture of the $\mathrm{C}_{\mathrm{S}}$-isomer and the racemic chiral $\mathrm{C}_{2}$-isomers is obtained. The cyclopentadienide $\mathrm{Na} 2$ was prepared in situ by the reaction between $\mathrm{NaC}_{5} \mathrm{H}_{5}$ and dibromobenzothiadiazole (see scheme 1). Reaction with $\mathrm{CrCl}_{3}(\text { thf })_{3}$ yields the chromium(III) complex 12.

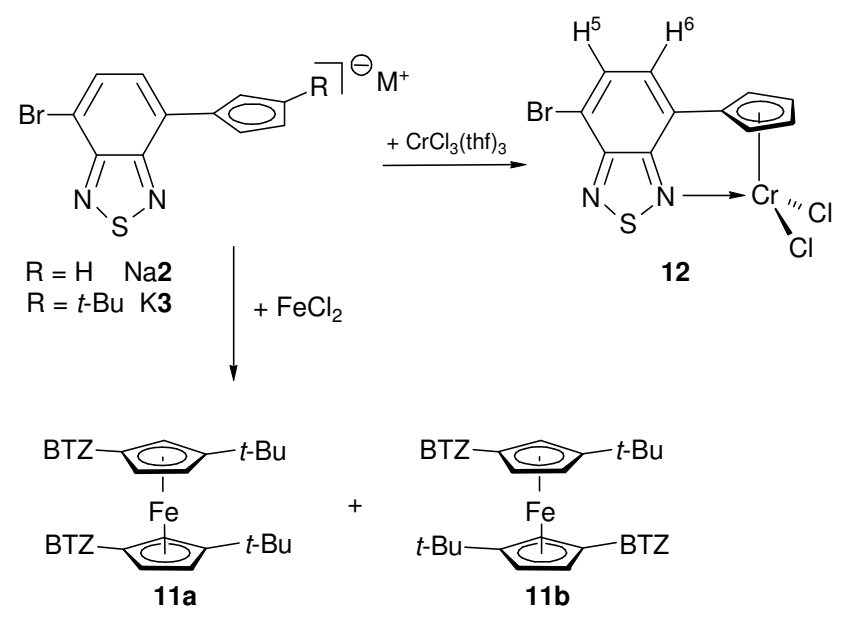

Scheme 6. Synthesis of the ferrocene derivatives $\mathbf{1 1}$ and Cr complex 12.

No crystals of 12, suitable for X-ray analysis have been obtained. The mass spectra (EI and HR-FAB) confirm the molecular formula. Complexes with BTZ as ligands are known, ${ }^{12}$ but ligand $\mathbf{2}$ is not ideally suited for a chelating coordination, as the lone-pair at the BTZ substituent is not pointing directly to the metal centre. This results in a constrained geometry of the complex. An other possibility would be a dimer formation with chloro bridges between two $\mathrm{Cr}$ centres or a coordination polymer. We calculated monomeric and dimeric molecular structures for $\mathbf{1 2}$ with DFTmethods and correlated the calculated Fermi-contact shifts with the experimental paramagnetic shifts observed in the ${ }^{1} \mathrm{H}-\mathrm{NMR}$ spectrum $\left(\delta_{\text {para }}=\delta_{\text {exp }}-\delta_{\text {dia }}\right)$. This procedure works well for 
chromium(III) complexes with quinolyl-Cp ligands. ${ }^{13}$ The theoretical relation between the Fermi-contact shift $\left(\delta_{\text {con }}\right)$ and the calculated Fermi contact couplings for a $S=3 / 2$ system is: ${ }^{14}$

$$
\delta_{\text {con }}=2.0051 \cdot 10^{5} \rho_{\alpha \beta}
$$

The experimental paramagnetic shift $\delta_{\text {para }}$ is the sum of $\delta_{c o n}$ and $\delta_{d i p}\left(\delta_{\text {dip }}\right.$ is the dipolar chemical shift contribution). For many $\mathrm{H}$-atoms in paramagnetic organometallic compounds the contact shift dominates so that $\delta_{\text {para }} \approx \delta_{\text {con }}$. A fitting of $\delta_{\text {para }}$ with $\rho_{\alpha \beta}$ with several $\mathrm{Cr}(\mathrm{III})-\mathrm{Cp}$-quinolyl complexes leads to the following modified relation: ${ }^{13}$

$$
\delta_{c o n}=1.8484 \cdot 10^{5} \rho_{\alpha \beta}+6.1 \mathrm{ppm}
$$

Deviations from this simple correlation are significant only for $\mathrm{H}$ atoms directly bound to the $\mathrm{Cp}$-Ring and for one position in the quinoline which corresponds to $\mathrm{H}^{6}$ in complex 12. The DFToptimized structure for monomeric $\mathbf{1 2}$ is depicted in Figure 4.

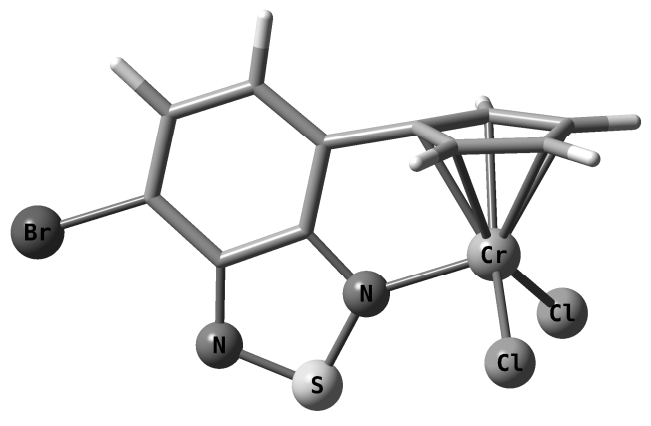

Figure 4. DFT-optimized structure of $\mathbf{1 2}$ (UB3LYP/6-311g(d)). ${ }^{15}$

Table 1 gives the experimental ${ }^{1} \mathrm{H}-\mathrm{NMR}$ shifts together with calculated chemical shifts using the equation above.

Table 1: Comparison of experimental ${ }^{1} \mathrm{H}-\mathrm{NMR}$ shifts with calculated shifts.

\begin{tabular}{ccccc}
\hline H-atom & $\delta_{(\exp )}$ & $\delta_{\text {(para) }}$ & $\rho_{\alpha \beta}$ [a.u. x $\left.10^{5}\right]$ & $\delta_{\text {con }}$ \\
\hline $\mathrm{H}-\mathrm{Cp}$ & 159 & 153 & $72 / 98$ & $139,2 / 187,2$ \\
$\mathrm{H}^{5}$ & 19 & 11 & 12 & 28,3 \\
$\mathrm{H}^{6}$ & 6.8 & -3 & -18 & $-27,2$
\end{tabular}

\section{Test of polymerization activity of Cr-complex 12}

Chromium(III) complexes with donorfunctionalized Cp ligands lead to highly active catalysts for the polymerization of olefins. ${ }^{2 \mathrm{c}-2 \mathrm{~g}}$ Related $\mathrm{Cp}$-Cr complexes with external donors are also active, but less stable. ${ }^{16}$ The catalytic activity for the polymerization of ethylene has been tested for $\mathbf{1 2}$ and the previously reported $\mathbf{1 3}^{14}$ and the results are compared with polymerization data using zirconocenedichloride as pre-catalyst under identical conditions.

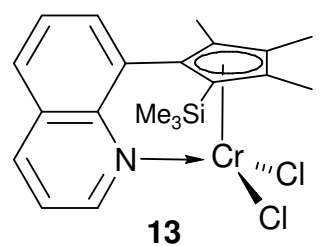

After activation with MAO (1000 equivalents of $\mathrm{Al}) \mathbf{1 2}$ polymerizes ethylene at room temperature and atmospheric pressure with medium activity. The activity of $\mathbf{1 3}$ is much higher and is comparable to the activity to other chromium complexes with 8-quinolyl-Cp ligands or to $\mathrm{Cp}_{2} \mathrm{ZrCl}_{2}$.

Table 2: Polymerization results ${ }^{\text {a) }}$

\begin{tabular}{cccc}
\hline Pre-catalyst & $\begin{array}{c}\text { activity }^{\mathrm{b})} \\
{\left[\mathrm{g} \mathrm{mmol}^{-1} \mathrm{~h}^{-1}\right]}\end{array}$ & $\mathrm{M}_{\mathrm{W}}$ & PDI \\
\hline $\mathbf{1 3}$ & 2550 & 247.000 & 2,7 \\
$\mathrm{Cp}_{2} \mathrm{ZrCl}_{2}$ & 2330 & 607.000 & 2,4 \\
$\mathbf{1 2}$ & 330 & 824.000 & 3.6
\end{tabular}

a) Polymerization conditions: $100 \mathrm{ml}$ toluene, $25^{\circ} \mathrm{C}, 3 \mu \mathrm{mol}$ Kat., 1000 eq. MAO (calcd. for ratio $\mathrm{Al}: \mathrm{Cr}(\mathrm{Zr})$ ), ethene pressure 1 bar, 20 min. b) Under the conditions used, activities greater 1500 become more and more levelled, as diffusion limitation leads to lower olefin concentrations.

\section{CONCLUSION}

We have developed the synthesis of benzothiadiazole (BTZ) and quinoxalyl substituted $\mathrm{Cp}$-ligands where one of the two $\mathrm{N}$-donor atoms is connected to the $\mathrm{Cp}$ ring by a rigid $\mathrm{C}_{2}$-spacer. This ligand geometry is comparable to the geometry in quinolyl substituted $\mathrm{Cp}$ ligands $\left(\mathrm{Cp}^{\mathrm{Q}}\right)$ developed earlier in our group. In addition, a second $\mathrm{N}$-donor is present in the new ligands which is located in a distal position relative to the metal centre. Due to the 5-membered ring in the BTZ ligand the chelating coordination is less favoured compared to $\mathrm{Cp}^{\mathrm{Q}}$-ligands. The chromium complex $\mathbf{1 2}$ derived from $\mathrm{Cp}^{\mathrm{BTZ}}$ is active as ethylene polymerization catalyst with moderate activity and produces polyethylene with high molecular weight.

\section{EXPERIMENTAL PART}

General Procedures. All experiments were carried out under an atmosphere of dry argon. Solvents were dried by using standard procedures and distilled prior to use. 4,7-dibromo-2,1,3-benzothiadiazole ${ }^{17}$, di- $\mu$ chlorotetrakis(ethene)dirhodium(I) ${ }^{18}, 1,1^{1}$-dilithioferrocene ${ }^{19}$ were prepared by literature procedures. All other reagents were used as purchased. NMRspectra were recorded on a Bruker DRX 200, Bruker Avance II 400 and Bruker Avance III 600 spectrometer $\left({ }^{1} \mathrm{H}: 200 \mathrm{MHz}, 400 \mathrm{MHz}\right.$ and 600 $\mathrm{MHz}$ respectively; ${ }^{13} \mathrm{C}: 50 \mathrm{MHz}, 100 \mathrm{MHz}$ and $150 \mathrm{MHz}$ respectively). The spectra were referenced using residual proton peaks or the ${ }^{13} \mathrm{C}$ solvent peaks. ${ }^{15} \mathrm{~N}$ NMR spectra were recorded on a Bruker Avance III 600 spectrometer equipped with a cryogenically cooled probe (QNPcryoprobe $^{\mathrm{TM}}$ ). Infrared spectra were obtained on a Varian 3100 FT-IR spectrometer (Excalibur Series). UV/Vis spectra have been measured in 1 $\mathrm{cm}$ cells with a Varian Cary 5000 spectrometer. Mass spectra and elemental analysis were performed by the analytical services at the OrganischChemisches Institut, University of Heidelberg. Complexes 10and 11 did not give satisfactory elemental analysis data. Cyclic voltammetry measurements were done with a PAR 263A potentiostat, a METROHM glassycarbon-disk working electrode, a saturated calomel reference electrode, and dichloromethane solvent with $0.1 \mathrm{~mol} \mathrm{~L} \mathrm{~L}^{-1}\left(\mathrm{n}-\mathrm{Bu}_{4}\right) \mathrm{NPF}_{6}$ as supporting electrolyte; the scan rate was $100 \mathrm{mV} \mathrm{s}^{-1}$. Molecular weight distributions of polyethylene were measured with a Polymer Lab HT-GPC (PL-GPC 220) at $150^{\circ} \mathrm{C}$ in 1,2,4-trichlorobenzene. Molecular masses are calibrated to PE. 4-Bromo-2,1,3-benzothiadiazol-7-yl-1-indene (H1) A solution of $711 \mathrm{mg}$ $(6.12 \mathrm{mmol})$ indene in $50 \mathrm{ml}$ thf was cooled to $-50^{\circ} \mathrm{C}$ and $3.8 \mathrm{ml}(6.12$ mmol) $n$-BuLi (1.6 M in hexane) were added dropwise and stirred at this temperature for 1 hour. At room temp. the solution was added via cannula to a solution of $1.09 \mathrm{~g}$ (3.70 mmol) of 4,7-dibromo-2,1,3-benzothiadiazole in $100 \mathrm{ml}$ thf. After 24 hours at room temp. a deep green reaction mixture was obtained. After addition of $100 \mathrm{ml}$ of aqueous $\mathrm{HCl}(5 \%)$ the mixture was treated with $\mathrm{NH}_{4} \mathrm{OH}$ until a $\mathrm{pH}$ of 12 was obtained. The layers were separated and the aqueous one was extracted twice with diethylether $(2 \mathrm{x}$ 
$100 \mathrm{ml}$ ). The organic layers were collected, dried over $\mathrm{MgSO}_{4}$, filtered and the volatile components were removed to obtain a yellow powder. After column chromatography $\left(\mathrm{Al}_{2} \mathrm{O}_{3}\right)$ with toluene as eluent and removing of the solvent a yellow powder was obtained. Yield: $1.10 \mathrm{~g}(3.34 \mathrm{mmol}=90 \%)$. ${ }^{1} \mathrm{H} \mathrm{NMR}\left(\mathrm{CDCl}_{3}, 200 \mathrm{MHz}\right) \delta=3.65\left(\mathrm{~d}, 2 \mathrm{H},{ }^{3} \mathrm{~J}(\mathrm{H}, \mathrm{H})=2.0 \mathrm{~Hz}, \mathrm{CH}_{2}\right), 7.10$ $\left(\mathrm{t}, 1 \mathrm{H},{ }^{3} \mathrm{~J}(\mathrm{H}, \mathrm{H})=2.0 \mathrm{~Hz}, H^{12}\right), 7.26-7.32\left(\mathrm{~m}, 2 \mathrm{H}_{\text {Ind }}\right), 7.43\left(\mathrm{~d}, 1 \mathrm{H},{ }^{3} \mathrm{~J}(\mathrm{H}, \mathrm{H})\right.$ $\left.=6.3 \mathrm{~Hz}, H_{\text {Ind }}\right), 7.57\left(\mathrm{~d}, 1 \mathrm{H},{ }^{3} \mathrm{~J}(\mathrm{H}, \mathrm{H})=6.3 \mathrm{~Hz}, H_{\text {Ind }}\right), 7.69\left(\mathrm{~d}, 1 \mathrm{H},{ }^{3} \mathrm{~J}(\mathrm{H}, \mathrm{H})\right.$ $\left.=7.5 \mathrm{~Hz}, H^{6}\right), 7.91\left(\mathrm{~d}, 1 \mathrm{H},{ }^{3} \mathrm{~J}(\mathrm{H}, \mathrm{H})=7.5 \mathrm{~Hz}, H^{5}\right) \mathrm{ppm} .{ }^{13} \mathrm{C} \mathrm{NMR}\left(\mathrm{CDCl}_{3}\right.$, $50 \mathrm{MHz}) \delta=38.9\left(\mathrm{CH}_{2}\right), 113.2\left(\mathrm{C}_{q}\right), 120.5\left(\mathrm{CH}^{12}\right), 124.3,125.3,126.2$, $128.1\left(4 \times C \mathrm{H}_{\text {Ind }}\right), 128.9\left(C_{q}\right), 132.1,136.1\left(\mathrm{CH}^{5}\right.$ and $\left.C \mathrm{H}^{6}\right), 139.9,143.3$, 144.2, 153.5, $153.8\left(5 \times C_{q}\right)$ ppm. ${ }^{15} \mathrm{~N}$ NMR $\left(\mathrm{C}_{6} \mathrm{D}_{6}, 61 \mathrm{MHz}\right) \delta=335.8$,

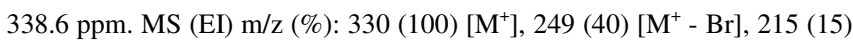
$\left[\mathrm{M}^{+}-\mathrm{Br}-\mathrm{H}_{2} \mathrm{~S}\right]-\mathrm{C}_{15} \mathrm{H}_{9} \mathrm{BrN}_{2} \mathrm{~S}$ (329.21) calc. C 54.72, H 2.76, N 8.51; found C 54.40, H 2.44, N 8.83 .

\section{4-Bromo-2,1,3-benzothiadiazol-7-yl-tert-butylcyclopentadiene (H3)}

To a solution of $1.64 \mathrm{~g}(15.4 \mathrm{mmol})$ of 6,6-dimethylfulvene in $30 \mathrm{ml}$ of diethylether was added $9.65 \mathrm{ml}(15.4 \mathrm{mmol})$ of methyllithium $(1.6 \mathrm{M}$ solution in diethylether) at $0^{\circ} \mathrm{C}$. After $5 \mathrm{~min}$ the solvent was evaporated and the resulting white solid was washed with diethylether, dried and dissolved in $50 \mathrm{ml}$ of thf. This solution was added to a solution of $2.70 \mathrm{~g}(9.3 \mathrm{mmol})$ of 4,7-dibromo-2,1,3-benzothiadiazole in $50 \mathrm{ml}$ of thf within $10 \mathrm{~min}$. The reaction mixture was heated to $40^{\circ} \mathrm{C}$ for $21 \mathrm{~h}$ to give an intensely blue colored solution which was then added to a saturated $\mathrm{NH}_{4} \mathrm{Cl}$ solution in water. The aqueous phase was extracted twice with $n$-hexane and the combined organic phases were dried over $\mathrm{MgSO}_{4}$, filtered and the solvent evaporated. The crude product was purified by chromatography $\left(\mathrm{Al}_{2} \mathrm{O}_{3}\right.$, eluent: toluene) to give $925 \mathrm{mg}(30 \%)$ of the two isomers of $\mathrm{H3}$ in a 1:1 ratio. Isomer $\mathrm{H3a}:{ }^{1} \mathrm{H} \mathrm{NMR}\left(\mathrm{CDCl}_{3}, 600 \mathrm{MHz}\right) \delta=1.25\left(\mathrm{~s}, 9 \mathrm{H}, \mathrm{CH}_{3}\right), 3.56$ $\left(\mathrm{dd}, 2 \mathrm{H},{ }^{4} \mathrm{~J}\left(\mathrm{H}^{9}, \mathrm{H}^{11}\right)=1.3 \mathrm{~Hz},{ }^{4} \mathrm{~J}\left(\mathrm{H}^{9}, \mathrm{H}^{12}\right)=1.3 \mathrm{~Hz}, H^{9}\right), 6.34\left(\mathrm{~m}, H^{11}\right), 7.39$ $\left(\mathrm{d}, 1 \mathrm{H},{ }^{3} \mathrm{~J}\left(\mathrm{H}^{6}, \mathrm{H}^{5}\right)=7.8 \mathrm{~Hz}, H^{6}\right), 7.73\left(\mathrm{~d}, 1 \mathrm{H},{ }^{3} \mathrm{~J}\left(\mathrm{H}^{5}, \mathrm{H}^{6}\right)=6.9 \mathrm{~Hz}, H^{5}\right), 7.77$ $\left(\mathrm{m}, H^{12}\right)$ ppm. ${ }^{13} \mathrm{C}$ NMR $\left(\mathrm{CDCl}_{3}, 100 \mathrm{MHz}\right) \delta=30.8\left(\mathrm{CH}_{3}\right), 32.3\left(C_{\mathrm{q}}\right), 40.9$ $\left(\mathrm{CH}_{2}\right), 110.4\left(C_{\mathrm{q}}\right), 124.2\left(\mathrm{CH}^{6}\right), 125.7\left(\mathrm{CH}^{1}\right), 132.3\left(\mathrm{CH}^{5}\right), 132.4\left(C_{\mathrm{q}}\right)$, $135.8\left(\mathrm{CH}^{12}\right), 139.1,152.5,154.0,161.5\left(4 \mathrm{x} C_{\mathrm{q}}\right) \mathrm{ppm}$. Isomer $\mathrm{H} 3 \mathbf{b}:{ }^{1} \mathrm{H}$ $\operatorname{NMR}\left(\mathrm{CDCl}_{3}, 600 \mathrm{MHz}\right) \delta=1.25\left(\mathrm{~s}, 9 \mathrm{H}, \mathrm{CH}_{3}\right), 3.54\left(\mathrm{dd}, 2 \mathrm{H},{ }^{3} \mathrm{~J}\left(\mathrm{H}^{12}, \mathrm{H}^{11}\right)=\right.$ $\left.1.5 \mathrm{~Hz},{ }^{4} \mathrm{~J}\left(\mathrm{H}^{12}, \mathrm{H}^{9}\right)=1.5 \mathrm{~Hz}, H^{12}\right), 6.12\left(\mathrm{td}, 1 \mathrm{H},{ }^{3} \mathrm{~J}\left(\mathrm{H}^{11}, \mathrm{H}^{12}\right)=1.5 \mathrm{~Hz}\right.$, $\left.{ }^{4} \mathrm{~J}\left(\mathrm{H}^{11}, \mathrm{H}^{9}\right)=1.6 \mathrm{~Hz}, H^{11}\right), 7.44\left(\mathrm{~d}, 1 \mathrm{H},{ }^{3} \mathrm{~J}\left(\mathrm{H}^{6}, \mathrm{H}^{5}\right)=7.8 \mathrm{~Hz}, H^{6}\right), 7.75(\mathrm{~d}, 1 \mathrm{H}$, $\left.{ }^{3} \mathrm{~J}\left(\mathrm{H}^{5}, \mathrm{H}^{6}\right)=6.9 \mathrm{~Hz}, H^{5}\right), 7.99\left(\mathrm{dt}, 1 \mathrm{H},{ }^{3} \mathrm{~J}\left(\mathrm{H}^{9}, \mathrm{H}^{11}\right)=1.6 \mathrm{~Hz},{ }^{4} \mathrm{~J}(\mathrm{H} 9, \mathrm{H} 12)=1.5\right.$ $\mathrm{Hz}, H 9)$ ppm. ${ }^{13} \mathrm{C}-\mathrm{NMR}\left(\mathrm{CDCl}_{3}, 100 \mathrm{MHz}\right) \delta=29.7\left(\mathrm{CH}_{3}\right), 33.6\left(C_{\mathrm{q}}\right), 41.4$ $\left(\mathrm{CH}_{2}\right), 111.0\left(C_{\mathrm{q}}\right), 123.9\left(\mathrm{CH}^{11}\right), 124.8\left(\mathrm{CH}^{10}\right), 132.3\left(\mathrm{CH}^{5}\right), 132.4\left(C_{\mathrm{q}}\right)$, $136.3\left(\mathrm{CH}^{9}\right), 141.9,152.5,154.0,158.8\left(4 \times C_{\mathrm{q}}\right) \mathrm{ppm} . \mathrm{MS}(\mathrm{EI}) \mathrm{m} / \mathrm{z}(\%)$ : $334(53)\left[\mathrm{M}^{+}\right], 321(100)\left[\mathrm{M}^{+}-\mathrm{CH}_{3}\right], 278(57)\left[\mathrm{M}^{+}-{ }^{\mathrm{t}} \mathrm{Bu}\right], 240(36)\left[\mathrm{M}^{+}-\right.$ $\left.\mathrm{CH}_{3}-\mathrm{Br}\right]$. UV/Vis (thf), $\lambda_{\max }[\mathrm{nm}]\left(\varepsilon\left[1 \mathrm{~mol}^{-1} \mathrm{~cm}^{-1}\right]\right): 306$ (9740), 438 (4550). Deprotonation with $\mathrm{KH}$ leads to the intensely colored anion $3 \mathrm{~K}$ : UV/Vis (thf), $\lambda_{\max }[\mathrm{nm}]\left(\varepsilon\left[1 \mathrm{~mol}^{-1} \mathrm{~cm}^{-1}\right]\right): 339$ (9700), 675 (5400).

\section{4-Bromo-2,1,3-benzothiadiazol-7-yl-tetramethylcyclopentadiene (4)}

A solution of lithium tetramethylcyclopentadienide in $50 \mathrm{ml}$ thf was prepared from $830 \mathrm{mg}$ (6.8 mmol) of 2,3,4,5-tetramethylcyclopentadiene and $4.25 \mathrm{ml}(6.8 \mathrm{mmol})$ of a $n$-BuLi solution $(1.6 \mathrm{M}$ in hexane). This solution was added to a solution of $1.0 \mathrm{~g}(3.4 \mathrm{mmol})$ 4,7-dibromo-2,1,3benzothiadiazole in $100 \mathrm{ml}$ thf at $-55^{\circ} \mathrm{C}$. The reaction mixture turned blue and after stirring at room temp. for $18 \mathrm{~h}$ the solution was violet. Diluted hydrochloric acid was added and the mixture was alkalized with $\mathrm{NH}_{4} \mathrm{OH}$ until a pH of 12 was obtained. The mixture was extracted with diethylether and the combined organic layers were dried with $\mathrm{MgSO}_{4}$. The product mixture was purified by chromatography and the main component was identified as compound 4. Yield $450 \mathrm{mg}(1.34 \mathrm{mmol}), 39 \%$. ${ }^{1} \mathrm{H}$ NMR $\left(\mathrm{CDCl}_{3}, 400 \mathrm{MHz}\right) \delta=1.68\left(\mathrm{~s}, 3 \mathrm{H}, \mathrm{CH}_{3}\right), 1.78\left(\mathrm{~s}, 3 \mathrm{H}, \mathrm{CH}_{3}\right), 1.85(\mathrm{~s}, 6 \mathrm{H}, 2$ x $\left.\mathrm{CH}_{3}\right), 6.24\left(\mathrm{~s}, 1 \mathrm{H}, H^{12}\right), 7.03\left(\mathrm{~d}, 1 \mathrm{H},{ }^{3} \mathrm{~J}(\mathrm{H}, \mathrm{H})=7.6, H^{6}\right), 7.63\left(\mathrm{~d}, 1 \mathrm{H},{ }^{3} \mathrm{~J}\right.$ $\left.(\mathrm{H}, \mathrm{H})=7.6, H^{5}\right)$ ppm. ${ }^{13} \mathrm{C}-\mathrm{NMR}\left(\mathrm{CDCl}_{3}, 100 \mathrm{MHz}\right): \delta=11.0,11.3,14.0$, $20.5\left(4 \times \mathrm{CH}_{3}\right), 58.8\left(\mathrm{C}_{\mathrm{q}}{ }^{8}\right), 111.8\left(\mathrm{C}_{\mathrm{q}}\right), 125.8\left(\mathrm{CH}^{6}\right), 132.2\left(\mathrm{CH}^{7}\right), 135.7\left(\mathrm{C}_{\mathrm{q}}\right)$, $136.1\left(\mathrm{CH}^{12}\right), 136.9,141.0,143.8\left(3 \times C_{\mathrm{q}}-\mathrm{Cp}\right), 154.0,154.4\left(2 \times C_{\mathrm{q}}\right) \mathrm{ppm}$. MS (EI) m/z (\%): $334(80)\left[\mathrm{M}^{+}\right], 319(50)\left[\mathrm{M}^{+}-\mathrm{CH}_{3}\right], 240(100)\left[\mathrm{M}^{+}-\mathrm{Br}-\right.$
$\left.\mathrm{CH}_{3}\right], 225(85)\left[\mathrm{M}^{+}-\mathrm{C}_{2} \mathrm{H}_{6}-\mathrm{Br}\right] . \mathrm{C}_{15} \mathrm{H}_{15} \mathrm{BrN}_{2} \mathrm{~S}$ (335.26) calcd. C 54.74, $\mathrm{H}$ 4.51, N 8.36; found C 53.89, H 4.52, N 8.28.

\section{4-Bromo-7-ferrocenyl-2,1,3-benzothiadiazole (5)}

To a solution of $1.50 \mathrm{~g}(8.1 \mathrm{mmol})$ of ferrocene in $30 \mathrm{ml}$ thf at $-40^{\circ} \mathrm{C}$ was added $5.5 \mathrm{ml}(6.7 \mathrm{mmol})$ of a $1.26 \mathrm{M}$ solution of $t$-BuLi in pentane. After stirring for $2 \mathrm{~h}$ at room temp. a solution of $884 \mathrm{mg}(6.5 \mathrm{mmol})$ of $\mathrm{ZnCl}_{2}$ was added and the resulting solution of ferrocenylzinc chloride was stirred for an additional hour. A solution of $\mathrm{Pd}\left(\mathrm{PPh}_{3}\right)_{2}$ (prepared from $235 \mathrm{mg}(0.35$ $\mathrm{mmol})$ of $\left(\mathrm{PPh}_{3}\right)_{2} \mathrm{PdCl}_{2}$ and $0.70 \mathrm{mmol}$ of DibAl-H) was added to the red solution of ferrocenylzinc chloride and subsequent $1.88 \mathrm{~g}(6.4 \mathrm{mmol})$ of 4,7-dibromobenzo-2,1,3-thiadiazole in $50 \mathrm{ml}$ thf was added. After stirring at room temp. for 5 days a deep violett solution was obtained which was treated with a solution of $5 \mathrm{~g}(0.2 \mathrm{~mol}) \mathrm{NaOH}$ in $100 \mathrm{ml} \mathrm{H}_{2} \mathrm{O}$. The layers were separated and the aqueous layer was extracted twice with $\mathrm{CH}_{2} \mathrm{Cl}_{2}$. The organic layers were dried with $\mathrm{MgSO}_{4}$, filtered and the volatile components were removed to obtain a violet powder with ferrocene impurity. Purification by column chromatography $\left(\mathrm{Al}_{2} \mathrm{O}_{3}\right.$ (neutral); eluent: toluene) led after removing of the solvent to violet crystals. Yield: $1.02 \mathrm{~g}$ (2.56 $\mathrm{mmol}), 40 \% .{ }^{1} \mathrm{H} \mathrm{NMR}\left(\mathrm{CDCl}_{3}, 400 \mathrm{MHz}\right) \delta=3.99(\mathrm{~s}, 5 \mathrm{H}, \mathrm{Cp}-H), 4.48(\mathrm{pt}$, $2 \mathrm{H}, \mathrm{Cp}-\mathrm{CH}), 5.22(\mathrm{pt}, 2 \mathrm{H}, \mathrm{Cp}-\mathrm{CH}), 7.52\left(\mathrm{~d}, 1 \mathrm{H},{ }^{3} \mathrm{~J}(\mathrm{H}, \mathrm{H})=7.7 \mathrm{~Hz}, H^{6}\right), 7.70$ $\left(\mathrm{d}, 1 \mathrm{H},{ }^{3} \mathrm{~J}(\mathrm{H}, \mathrm{H})=7.7 \mathrm{~Hz}, H^{5}\right) \mathrm{ppm} .{ }^{13} \mathrm{C} \mathrm{NMR}\left(\mathrm{CDCl}_{3}, 150 \mathrm{MHz}\right) \delta=68.9$ $\left(\mathrm{CH}\left(\mathrm{C}_{5} \mathrm{H}_{5}\right), 70.0,70.1\left(2 \times \mathrm{CH}\left(\mathrm{C}_{5} \mathrm{H}_{4}\right), 68.3\left(\mathrm{C}_{\mathrm{q}}\right), 113.7\left(\mathrm{C}_{\mathrm{q}}\right), 132.3,132.6\right.\right.$ $\left(\mathrm{CH}^{5}\right.$ and $\left.\mathrm{CH}^{6}\right), 133.9,152.8,152.9\left(3 \times \mathrm{C}_{\mathrm{q}}\right) \mathrm{ppm}$. MS (EI) m/z (\%): 398 $\left(\mathrm{M}^{+}, 100\right), 333\left(\mathrm{M}^{+}-\mathrm{Cp}, 25\right), 277\left(\mathrm{M}^{+}-\mathrm{FeCp}, 18\right)$. MS (HR-FAB) calcd. 397.9176; found 397.9180.

\section{4,7-(Bis-ferrocenyl)-2,1,3-benzothiadiazole (6)}

A solution of 1,1'-bis-chlorozinc-ferrocene in $100 \mathrm{ml}$ thf was prepared from $3.11 \mathrm{~g}$ (11.7 mmol) 1,1'-dilithioferrocene x 2/3 TMEDA and $3.18 \mathrm{~g}$ (23.3 $\mathrm{mmol}) \mathrm{ZnCl}_{2}$. A solution of $\left(\mathrm{PPh}_{3}\right)_{2} \mathrm{Pd}$ (prepared from $170 \mathrm{mg}(0.23 \mathrm{mmol})$ of $\left(\mathrm{PPh}_{3}\right)_{2} \mathrm{PdCl}_{2}$ and $0.48 \mathrm{mmol}$ of DibAl-H) and $2.0 \mathrm{~g}(6.8 \mathrm{mmol})$ of $4,7-$ dibromo-2,1,3-benzothiadiazole in $20 \mathrm{ml}$ thf were added slowly to the reaction mixture leading to a deep red solution. After 3 days stirring at room temp. $10 \mathrm{~g}(0.23 \mathrm{~mol}) \mathrm{NaOH}$ in $100 \mathrm{ml} \mathrm{H}_{2} \mathrm{O}$ were added. After extraction with $\mathrm{CH}_{2} \mathrm{Cl}_{2}(2 \times 100 \mathrm{ml})$ the organic layers were dried with $\mathrm{MgSO}_{4}$ and the solvent was removed. Column chromatography $\left(\mathrm{Al}_{2} \mathrm{O}_{3}\right.$ (neutral), eluent: toluene) led to a violet powder. Yield: $0.81 \mathrm{~g}(1.61 \mathrm{mmol})$, $24 \% .{ }^{1} \mathrm{H}$ NMR $\left(\mathrm{C}_{6} \mathrm{D}_{6}, 200 \mathrm{MHz}\right) \delta=3.95(\mathrm{~s}, 10 \mathrm{H}, \mathrm{Cp}-H), 4.33$ (pt, $4 \mathrm{H}$, $\mathrm{Cp}-H), 5.33$ (pt, $4 \mathrm{H}, \mathrm{Cp}-H), 7.41$ (s, $2 \mathrm{H}, \mathrm{CH}) \mathrm{ppm} .{ }^{13} \mathrm{C}$ NMR $\left(\mathrm{C}_{6} \mathrm{D}_{6}, 50\right.$ $\mathrm{MHz}) \delta=68.9,69.9\left(2 \times \mathrm{CH}\left(\mathrm{C}_{5} \mathrm{H}_{4}\right)\right), 70.1\left(\mathrm{CH}\left(\mathrm{C}_{5} \mathrm{H}_{5}\right)\right), 82.2\left(C_{\mathrm{q}}-\mathrm{Cp}\right), 125.5$ $(\mathrm{CH}), 131.2,154.6\left(2 \times C_{\mathrm{q}}\right)$ ppm. $-\mathrm{MS}\left(\mathrm{FAB}^{+}\right) \mathrm{m} / \mathrm{z}(\%) 504(100)\left[\mathrm{M}^{+}\right]$. $\mathrm{C}_{26} \mathrm{H}_{20} \mathrm{~N}_{2} \mathrm{SFe}_{2}$ (504.21) calcd. C 61.93, H 4.00, N 5.56; found C 61.87, H $4.47, \mathrm{~N} 5.18 . \mathrm{CV}: \mathrm{E}^{0 / 1}=0.455 \mathrm{~V}$ and $=0.555 \mathrm{~V}$ vs. SCE.

\section{5,8-(Bis-ferrocenyl)-quinoxaline (7)}

A solution of 1,1'-(bis-chlorozinc)ferrocene in $100 \mathrm{ml}$ thf was prepared from $2.01 \mathrm{~g}$ (7.55 mmol) 1,1'-dilithioferrocene x 2/3 TMEDA and $2.04 \mathrm{~g}$ (15.1 mmol) $\mathrm{ZnCl}_{2}$. A solution of $\left(\mathrm{PPh}_{3}\right)_{2} \mathrm{Pd}$ (prepared from $265 \mathrm{mg}(0.38$ $\mathrm{mmol})$ of $\left(\mathrm{PPh}_{3}\right)_{2} \mathrm{PdCl}_{2}$ and $0.76 \mathrm{mmol}$ of DibAl-H) and $0.55 \mathrm{~g}(1.9 \mathrm{mmol})$ of 4,7-dibromo-2,1,3-benzothiadiazole in $20 \mathrm{ml}$ thf were added slowly to the reaction mixture leading to a red-violet solution. After 5 days stirring at room temp. $10 \mathrm{~g}(0.23 \mathrm{~mol}) \mathrm{NaOH}$ in $100 \mathrm{ml} \mathrm{H}_{2} \mathrm{O}$ were added. After extraction with $\mathrm{CH}_{2} \mathrm{Cl}_{2}(2 \times 100 \mathrm{ml})$ the organic layers were dried with $\mathrm{MgSO}_{4}$ and the solvent was removed. Column chromatography $\left(\mathrm{Al}_{2} \mathrm{O}_{3}\right.$ (neutral), eluent: toluene) led to red-violet crystals. Yield: $0.33 \mathrm{~g}$ (0.66 $\mathrm{mmol}), 35 \%$. ${ }^{1} \mathrm{H}$ NMR $\left(\mathrm{CDCl}_{3}, 200 \mathrm{MHz}\right) \delta=4.09(\mathrm{~s}, 10 \mathrm{H}, \mathrm{Cp}-H), 4.46$ (pt, 4H, Cp-CH), 5.18 (pt, 4H, Cp-CH), 7.99 (s, 2H, $H^{6}$ and $\left.H^{7}\right), 8.86(\mathrm{~s}, 2 \mathrm{H}$, $H^{2}$ and $\left.H^{3}\right) \mathrm{ppm} .{ }^{13} \mathrm{C} \mathrm{NMR}\left(\mathrm{CDCl}_{3}, 50 \mathrm{MHz}\right) \delta=69.1\left(\mathrm{CH}\left(\mathrm{C}_{5} \mathrm{H}_{4}\right)\right), 69.4$ $\left(\mathrm{CH}\left(\mathrm{C}_{5} \mathrm{H}_{5}\right)\right), 70.5\left(\mathrm{CH}\left(\mathrm{C}_{5} \mathrm{H}_{4}\right)\right), 82.6\left(C_{\mathrm{q}^{-}} \mathrm{Cp}\right), 128.7\left(C^{6}\right.$ and $\left.C^{7}\right), 136.5$, $141.4\left(2 \times C_{\mathrm{q}}\right), 142.9\left(C^{2}\right.$ and $\left.C^{3}\right) \mathrm{ppm}$. MS $\left(\mathrm{FAB}^{+}\right) \mathrm{m} / \mathrm{z}(\%) 498(100)\left[\mathrm{M}^{+}\right]$,

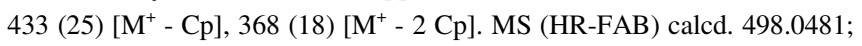
found 498.0470. $\mathrm{C}_{28} \mathrm{H}_{22} \mathrm{Fe}_{2} \mathrm{~N}_{2}$ (498.05): calcd. C 67.51, $\mathrm{H} \mathrm{4.45,} \mathrm{N} \mathrm{5.62;}$ found C 67.96, H 4.63, N 5.40. CV: $\mathrm{E}^{0 /+1}=0.415 \mathrm{~V}$ and $0.495 \mathrm{~V}$ vs. SCE. $\eta^{5}$-(5,8-Bis-cyclopentadienylchinoxalyl)]rhenium(I) (8) 
A solution of $\left(\mathrm{ClZnC}_{5} \mathrm{H}_{4}\right) \mathrm{Re}(\mathrm{CO})_{3}$ was prepared by addition of $5.4 \mathrm{ml}(4.0$ $\mathrm{mmol})$ of $n-\mathrm{BuLi}(1.6 \mathrm{M}$ in hexane) to a solution of $1.21 \mathrm{~g}$ (3.6 mmol) of $\mathrm{C}_{5} \mathrm{H}_{5} \mathrm{Re}(\mathrm{CO})_{3}$ in $70 \mathrm{ml}$ of thf at $-78^{\circ} \mathrm{C}$. After $1 \mathrm{~h}$ at this temperature a solution of $\mathrm{ZnCl}_{2}$ in $70 \mathrm{ml}$ of thf was added. 1h later, a solution of $\left(\mathrm{PPh}_{3}\right)_{2} \mathrm{Pd}$ (prepared from $140 \mathrm{mg}(0.2 \mathrm{mmol})$ of $\left(\mathrm{PPh}_{3}\right)_{2} \mathrm{PdCl}_{2}$ and $0.4 \mathrm{ml}$ $(0.4 \mathrm{mmol})$ of DibAl-H (1M in hexane)) and subsequently a solution of $1.04 \mathrm{~g}(3.6 \mathrm{mmol})$ of 5,8-dibromoquinoxaline in $20 \mathrm{ml}$ of thf was added. The reaction mixture was allowed to warm to room temp. and after stirring for 5 days $100 \mathrm{ml}$ of $\mathrm{NaOH}$ solution was added. The product was extracted with $\mathrm{CH}_{2} \mathrm{Cl}_{2}$ and purified by chromatography $\left(\mathrm{Al}_{2} \mathrm{O}_{3} /\right.$ toluene $)$ to give $1.86 \mathrm{~g}$ ( $2.34 \mathrm{mmol}, 65 \%)$ of yellow solid $8 .{ }^{1} \mathrm{H} \mathrm{NMR}\left(\mathrm{CDCl}_{3}, 400 \mathrm{MHz}\right) \delta=5.46$ (pt, $\left.4 \mathrm{H}, \mathrm{CH}_{\mathrm{Cp}}\right), 6.32\left(\mathrm{pt}, 4 \mathrm{H}, \mathrm{CH}_{\mathrm{Cp}}\right), 7.81(\mathrm{~s}, 2 \mathrm{H}), 8.90(\mathrm{~s}, 2 \mathrm{H}) \mathrm{ppm} .{ }^{13} \mathrm{C}-$ NMR: $\left(\mathrm{CDCl}_{3}, 100 \mathrm{MHz}\right): \delta=84.4,88.3\left(\mathrm{CH}_{\mathrm{Cp}}\right), 100.7\left(C_{\mathrm{q}}-\mathrm{Cp}\right), 128.5$ $(\mathrm{CH}), 131.5,140.5\left(2 \times C_{\mathrm{q}}\right), 143.8(\mathrm{CH}), 194.2(\mathrm{CO}) \mathrm{ppm}$. MS (EI) m/z (\%): $796(10)\left[\mathrm{M}^{+}\right], 768(40)\left[\mathrm{M}^{+}-\mathrm{CO}\right], 740(40)\left[\mathrm{M}^{+}-2 \mathrm{CO}\right], 712$ (38) [M+- $3 \mathrm{CO}], 684(25)\left[\mathrm{M}^{+}-4 \mathrm{CO}\right], 656(20)\left[\mathrm{M}^{+}-5 \mathrm{CO}\right], 628(20)\left[\mathrm{M}^{+}-6\right.$ CO]. FT-IR (toluene) $v$ (tilde) $\left(\mathrm{cm}^{-1}\right)=2021\left(\mathrm{~s}, v_{\mathrm{C}=0}\right), 1928\left(\mathrm{~s}, v_{\mathrm{C}=0}\right)$. $\mathrm{C}_{24} \mathrm{H}_{12} \mathrm{~N}_{2} \mathrm{O}_{6} \mathrm{Re}_{2}$ (796.78): calcd. C 36.18, H 1.52, N 3.52; found C 36.12, H $1.68, \mathrm{~N} 3.61$.

\section{$\eta^{5}$-(4-Bromobenzo-2,1,3-thiadiazol-7-yl-indenyl)-}

tris(dimethylamido)zirconium (9) In a teflon valve NMR-tube $15 \mathrm{mg}$ (46 $\mu \mathrm{mol})$ of $\mathrm{H1}$ was dissolved in $\mathrm{C}_{6} \mathrm{D}_{6}$ and $12 \mathrm{mg}(46 \mu \mathrm{mol})$ of tetrakis(dimethylamido)zirconium(IV) was added. The solution turned into deep red. NMR spectra were recorded and showed compound 9 together with one equivalent of $\mathrm{HNMe}_{2}$. Yield: $>90 \%$ (not isolated). ${ }^{1} \mathrm{H} \mathrm{NMR}\left(\mathrm{C}_{6} \mathrm{D}_{6}\right.$ $600 \mathrm{MHz}) \delta=2.69\left(\mathrm{~s}, 18 \mathrm{H}, 3 \times \mathrm{N}\left(\mathrm{CH}_{3}\right)_{2}\right), 6.56\left(\mathrm{dd}, 1 \mathrm{H},{ }^{3} \mathrm{~J}\left(\mathrm{H}^{11}, \mathrm{H}^{12}\right)=3.6\right.$ $\left.\mathrm{Hz},{ }^{4} \mathrm{~J}\left(\mathrm{H}^{11}, \mathrm{H}_{\text {Ind }}\right)=0.6 \mathrm{~Hz}, \mathrm{C} H^{11}\right), 7.09\left(\mathrm{ddd}, 1 \mathrm{H},{ }^{3} \mathrm{~J}=8.3 \mathrm{~Hz},{ }^{3} \mathrm{~J}=6.5 \mathrm{~Hz},{ }^{4} \mathrm{~J}\right.$ $\left.=0.9 \mathrm{~Hz}, H_{\text {Ind }}\right), 7.16\left(\mathrm{ddd},{ }^{3} \mathrm{~J}=8.3 \mathrm{~Hz},{ }^{3} \mathrm{~J}=6.5 \mathrm{~Hz},{ }^{4} \mathrm{~J}=0.9 \mathrm{~Hz} 1 \mathrm{H}, H 3^{\prime}\right.$ ), $7.56\left(\mathrm{~d}, 1 \mathrm{H},{ }^{3} \mathrm{~J}=7.7 \mathrm{~Hz}, \mathrm{CH} H^{5}\right.$ or $\left.\mathrm{C} H^{6}\right), 7.59\left(\mathrm{~d}, 1 \mathrm{H},{ }^{3} \mathrm{~J}=7.7 \mathrm{~Hz}, \mathrm{CH}^{5}\right.$ or $\left.\mathrm{C} H^{6}\right), 7.67\left(\mathrm{ddd}, 1 \mathrm{H},{ }^{3} \mathrm{~J}=8.3 \mathrm{~Hz},{ }^{4} \mathrm{~J}=0.9 \mathrm{~Hz},{ }^{5} \mathrm{~J}=0.9 \mathrm{~Hz}, H_{\text {Ind }}\right), 7.71(\mathrm{~d}, 1 \mathrm{H}$, $\left.{ }^{3} \mathrm{~J}\left(\mathrm{H}^{11}, \mathrm{H}^{12}\right)=3.6 \mathrm{~Hz}, \mathrm{CH}{ }^{12}\right), 7.99\left(\mathrm{dddd}, 1 \mathrm{H},{ }^{3} \mathrm{~J}=8.3 \mathrm{~Hz},{ }^{4} \mathrm{~J}=0.6 \mathrm{~Hz},{ }^{4} \mathrm{~J}=\right.$ $\left.0.9,{ }^{5} \mathrm{~J}=0.9 \mathrm{~Hz}, H_{\text {Ind }}\right) \mathrm{ppm} .{ }^{13} \mathrm{C} \mathrm{NMR}\left(\mathrm{C}_{6} \mathrm{D}_{6}, 150 \mathrm{MHz}\right) \delta=43.8\left(\mathrm{~N}\left(\mathrm{CH}_{3}\right)_{2}\right)$, $99.1\left(\mathrm{CH}^{11}\right), 108.3,110.5\left(2 \times C_{\mathrm{q}}\right), 119.8\left(\mathrm{CH}^{12}\right), 121.8,123.0\left(2 \times \mathrm{CH}_{\text {Ind }}\right)$, 123.6 $\left(C_{\mathrm{q}}\right), 123.7,123.8\left(2 \times \mathrm{CH}_{\text {Ind }}\right), 126.2\left(\mathrm{CH}^{5}\right.$ or $\left.C \mathrm{H}^{6}\right), 127.4,129.9\left(C_{\mathrm{q}}\right)$, $132.3\left(\mathrm{CH}^{5}\right.$ or $\left.\mathrm{CH}^{6}\right), 153.6,154.1\left(2 \times C_{\mathrm{q}}\right)$ ppm. ${ }^{15} \mathrm{~N}$ NMR $\left(\mathrm{C}_{6} \mathrm{D}_{6}, 61 \mathrm{MHz}\right)$ : $\delta=333.7,336.6 \mathrm{ppm}$.

$\boldsymbol{\eta}^{5}$-(4-Bromo-2,1,3-benzothiadiazol-7-yl-indenyl)-bis $\left(\boldsymbol{\eta}^{2}\right.$-ethen)]rhodium (10) In a schlenk flask $99 \mathrm{mg}(0.30 \mathrm{mmol})$ of $\mathrm{H1}$ was dissolved in $20 \mathrm{ml}$ thf and $12 \mathrm{mg}(0.30 \mathrm{mmol}) \mathrm{KH}$ was added. After 12 hours stirring at room temp. the solution turned green. A solution of $58 \mathrm{mg}(0.15 \mathrm{mmol})$ $\left[\mathrm{ClRh}\left(\mathrm{C}_{2} \mathrm{H}_{4}\right)_{2}\right]_{2}$ in $20 \mathrm{ml}$ toluene was added dropwise. The reaction mixture was stirred for 24 hours and became red. After removing of the solvent in vacuum a red powder was obtained. After extraction with toluene and filtration of non-soluble residues, the product was purified by column chromatography $\left(\mathrm{Al}_{2} \mathrm{O}_{3}\right.$ (neutral), eluent: toluene). The product was obtained as a red powder. Yield: $66 \mathrm{mg}(0.13 \mathrm{mmol}), 45 \%$. ${ }^{1} \mathrm{H}$ NMR $\left(\mathrm{CDCl}_{3}, 400 \mathrm{MHz}\right) \delta=1.90,2.22\left(\mathrm{br}, 8 \mathrm{H}, \mathrm{CH}_{2}\right), 5.18\left(\mathrm{~d}, 1 \mathrm{H},{ }^{3} \mathrm{~J}(\mathrm{H}, \mathrm{H})=2.4\right.$ $\left.\mathrm{Hz}, H_{\mathrm{Cp}}\right) ; 7.24-7.27\left(\mathrm{~m}, 3 \mathrm{H}, 2 \times H_{\text {Ind }}\right.$ and $\left.H_{\mathrm{Cp}}\right), 7.46\left(\mathrm{~d}, 1 \mathrm{H},{ }^{3} \mathrm{~J}(\mathrm{H}, \mathrm{H})=7.3\right.$ $\left.\mathrm{Hz}, H_{\text {Ind }}\right), 7.52\left(\mathrm{~d}, 1 \mathrm{H},{ }^{3} \mathrm{~J}(\mathrm{H}, \mathrm{H})=7.9 \mathrm{~Hz}, H^{6}\right), 7.63\left(\mathrm{~d}, 1 \mathrm{H},{ }^{3} \mathrm{~J}(\mathrm{H}, \mathrm{H})=7.3\right.$, $\left.H_{\text {Ind }}\right), 7.88\left(\mathrm{~d}, 1 \mathrm{H},{ }^{3} \mathrm{~J}(\mathrm{H}, \mathrm{H})=7.9 \mathrm{~Hz}, H^{5}\right) \mathrm{ppm} .{ }^{13} \mathrm{C} \mathrm{NMR}\left(\mathrm{CDCl}_{3}, 100 \mathrm{MHz}\right)$ $\delta=47.7\left(\mathrm{~d},{ }^{1} \mathrm{~J}(\mathrm{Rh}, \mathrm{C})=13.7 \mathrm{~Hz}, C_{2} \mathrm{H}_{4}\right), 78.2\left(\mathrm{~d},{ }^{1} \mathrm{~J}(\mathrm{Rh}, \mathrm{C})=4.9 \mathrm{~Hz}, C_{\mathrm{Cp}}\right)$, $95.1\left(\mathrm{~d},{ }^{1} \mathrm{~J}(\mathrm{Rh}, \mathrm{C})=5.2 \mathrm{~Hz}, \mathrm{CH}_{\mathrm{Cp}}\right), 110.9,111.6\left(2 \times \mathrm{C}_{\mathrm{q}}\right), 112.5\left(\mathrm{~d},{ }^{1} \mathrm{~J}(\mathrm{Rh}, \mathrm{C})\right.$ $\left.=2.6 \mathrm{~Hz}, C_{q}\right), 118.3,120.6,123.9,124.5\left(4 \times \mathrm{CH}_{\text {Ind }}\right), 126.6\left(\mathrm{CH}^{6}\right), 128.2$, $128.5\left(2 \times C_{\mathrm{q}}\right), 132.3\left(\mathrm{CH}^{5}\right), 153.1,154.2\left(2 \times C_{\mathrm{q}}\right) \mathrm{ppm} . \mathrm{MS}\left(\mathrm{FAB}^{+}\right) \mathrm{m} / \mathrm{z}$ (\%): 430 (7) $\left[\mathrm{M}^{+}-2 \mathrm{C}_{2} \mathrm{H}_{4}\right], 327$ (100) [M+ - $\left.2 \mathrm{C}_{2} \mathrm{H}_{4}-\mathrm{Rh}\right]$.

Bis-[ $\boldsymbol{\eta}^{5}$-(4-bromo-2,1,3-benzothiadiazol-7-yl)-cyclopentadienyl]iron (11) To a solution of $183 \mathrm{mg}(0.54 \mathrm{mmol})$ 4-bromo-2,1,3-benzothiadiazol-7-yl-tbutylcyclopentadiene in $10 \mathrm{ml}$ thf was added $22 \mathrm{mg}(0.55 \mathrm{mmol})$ of potassium hydride. After $10 \mathrm{~h}$ stirring at room temperature this solution is dropped into a suspension of $40 \mathrm{mg}(0.32 \mathrm{mmol}) \mathrm{FeCl}_{2}$ in $10 \mathrm{ml}$ of thf. After $2 \mathrm{~d}$ the solvent is evaporated and the crude product is purified by chromatography $\left(\mathrm{Al}_{2} \mathrm{O}_{3}\right.$, toluene:hexane $\left.=2: 1\right)$. Yield $219 \mathrm{mg}(0.3 \mathrm{mmol})$, $56 \% .{ }^{1} \mathrm{H}$ NMR $\left(\mathrm{CDCl}_{3}, 600 \mathrm{MHz}\right) \delta=1.01,1.24\left(2 \times \mathrm{x} \mathrm{s}, 2 \times 9 \mathrm{H}, \mathrm{CH}_{3}\right), 4.59$,
4.75, 4.98 (3 x Cp-H), 4.67, 5.01, 5.79 (3 x Cp-H), 6.56, 6.94 ( 2 x Btz-H), 7.44, 7.69 (2 x Btz-H). MS (EI): m/z (\%): 724 (22) [M+], 644 (8) [M+ - Br], $\left.566(13)[\mathrm{M}+-2 \times \mathrm{Br}] . \mathrm{UV} / \mathrm{Vis}(\mathrm{thf}), \lambda_{\max }[\mathrm{nm}](\varepsilon)\left[1 \mathrm{~mol}^{-1} \mathrm{~cm}^{-1}\right]\right): 290$ (76000), 388 (36000), 562 (11000).

\section{[ $\boldsymbol{\eta}^{5}$-(4-Bromo-2,1,3-benzothiadiazol-7-yl)-cyclopentadienyl]-} chromium(III)dichloride (12)

A solution of $555 \mathrm{mg}(6.3 \mathrm{mmol})$ sodium cyclopentadienide in $60 \mathrm{ml}$ thf was added dropwise to $929 \mathrm{mg}$ (3.16 mmol) 4,7-dibromo-2,1,3benzothiadiazole in $70 \mathrm{ml}$ thf. The reaction mixture was stirred at room temp. for $24 \mathrm{~h}$ leading to a deep blue color. This solution was added slowly via a cannula to $1.18 \mathrm{~g}(3.16 \mathrm{mmol}) \mathrm{CrCl}_{3}(\mathrm{thf})_{3}$ in $80 \mathrm{ml}$ of thf. After 2 days at room temp. the reaction mixture turned to intensely green. Removal of the solvent led to a green powder which was washed with hexane and the product was extracted with toluene. After evaporation of the solvent 490 $\mathrm{mg}(1.22 \mathrm{mmol}, 39 \%)$ of the solid green complex 11 were isolated. ${ }^{1} \mathrm{H}$ NMR $\left(\mathrm{C}_{6} \mathrm{D}_{6}, 400 \mathrm{MHz}\right) \delta=159\left(\mathrm{~s}, v^{1 / 2} \sim 4000 \mathrm{~Hz}, \mathrm{CH}_{\mathrm{Cp}}\right), 19\left(\mathrm{~s}, v^{1 / 2} \sim 500\right.$

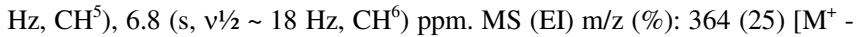
$\mathrm{Cl}], 329$ (100) [M+ - $2 \mathrm{Cl}$. MS (HR-FAB) $\mathrm{C}_{11} \mathrm{H}_{6} \mathrm{~N}_{2}{ }^{79} \mathrm{Br}^{35} \mathrm{ClSCr}$ calcd. 363.8529 ; found 363.8555 .

\section{Crystal structure determinations}

Crystal data. H1: $\mathrm{C}_{15} \mathrm{H}_{9} \mathrm{BrN}_{2} \mathrm{~S}$, monoclinic, space group $P 2_{1}, a=$ 19.1008(14), $b=7.4055(6), c=19.1311(14) \AA, \beta=109.4620(10)^{\circ}, V=$ 2551.5(3) $\AA^{3}, Z=8, \mu=3.370 \mathrm{~mm}^{-1}, F_{000}=1312 . T=100(2) \mathrm{K}, \theta$ range 1.1 to $30.1^{\circ}$. Index ranges $h, k, l$ (indep. set): $-26 \ldots 26,-10 \ldots 10,-26 \ldots 26$. Reflections measd.: 59944, indep.: $14928\left[R_{\text {int }}=0.0448\right]$, obsvd. $[I>$ $2 \sigma(I)]: 13768$. Final $R$ indices $\left[F_{\mathrm{O}}>4 \sigma\left(F_{\mathrm{O}}\right)\right]: R(F)=0.0313, w R\left(F^{2}\right)=$ 0.0620 , GooF $=1.018$. Pseudo-merohedral and racemic twin. 7: $\mathrm{C}_{28} \mathrm{H}_{22} \mathrm{Fe}_{2} \mathrm{~N}_{2}$, monoclinic, space group $P 2_{1} / c, a=14.2530(16), b=$ 7.4496(8), $c=22.8163(19) \AA, \beta=123.218(5)^{\circ}, V=2026.7(4) \AA^{3}, Z=4, \mu$ $=1.452 \mathrm{~mm}^{-1}, F_{000}=1024 . T=100(2) \mathrm{K}, \theta$ range 1.7 to $32.0^{\circ}$. Index ranges $h, k, l$ (indep. set): $-21 \ldots 20,-11 \ldots 0,-34 \ldots 19$. Reflections measd.: 34112 , indep.: $6945\left[R_{\text {int }}=0.0645\right]$, obsvd. $[I>2 \sigma(I)]: 5121$. Final $R$ indices $\left[F_{\mathrm{O}}\right.$ $\left.>4 \sigma\left(F_{\mathrm{O}}\right)\right]: R(F)=0.0410, \quad w R\left(F^{2}\right)=0.1081$, GooF $=1.058 . \quad 8:$ $\mathrm{C}_{24} \mathrm{H}_{12} \mathrm{~N}_{2} \mathrm{O}_{6} \mathrm{Re}_{2}$, triclinic, space group $P-1, a=8.0187(16), b=9.5933(19)$, $c=15.026(3) \AA, \alpha=71.948(4), \beta=123.218(5), \gamma=82.969(4){ }^{\circ}, V=$ 1072.8(4) $\AA^{3}, Z=2, \mu=2.467 \mathrm{~mm}^{-1}, F_{000}=736 . T=150(2) \mathrm{K}, \theta$ range 2.2 to $32.2^{\circ}$. Index ranges $h, k, l$ (indep. set): $-11 \ldots 11,-13 \ldots 14,0 \ldots 22$. Reflections measd.: 28868, indep.: $7906\left[R_{\text {int }}=0.0839\right]$, obsvd. $[I>2 \sigma(I)]$ : 5934. Final $R$ indices $\left[F_{\mathrm{O}}>4 \sigma\left(F_{\mathrm{O}}\right)\right]: R(F)=0.0703, w R\left(F^{2}\right)=0.1096$, $G o o F=1.002$. Pseudo-merohedral twin.

Intensity data collection: Bruker AXS Smart $1000 \mathrm{CCD}$ diffractometer, Mo$\mathrm{K}_{\alpha}$ radiation, graphite monochromator, $\lambda=0.71073 \AA$ A. Structure solution: conventional direct methods ${ }^{20,21}$ (H1 and 8) or heavy atom method combined with structure expansion by direct methods ${ }^{22}$ (7). Refinement: full-matrix least squares methods based on $F^{2}$; all non-hydrogen atoms anisotropic. Hydrogen atoms were input at calculated positions and refined riding (H1 and 8) or fully refined (7) ${ }^{23,}{ }^{21}$ The twin refinements were against all overlapping and non-overlapping reflections. Crystallographic data (excluding structure factors) for the structures reported in this paper have been deposited with the Cambridge Crystallographic Data Center: CCDC-713319 (H1), -713317 (7) and -713318 (8). These data can be obtained free of charge at http://www.ccdc.cam.ac.uk/cgi-bin/catreq.cgi? [or from CCDC, 12 Union Road, Cambridge CB2 1EZ, UK; Phone: +44 1223 336408, Fax: +44 1223 336033; E-mail: deposit@ccdc.cam.ac.uk].

\section{Acknowledgments}

This work was supported by the Deutsche Forschungsgemeinschaft (SFB $623)$. 
1 Review articles: a) J. Okuda, Comm. Inorg. Chem. 1994, 16, 185-205; b) P. Jutzi, U. Siemeling, J. Organomet. Chem. 1995, 500, 175-185; c) P. Jutzi, T. Redeker, Eur. J. Inorg. Chem. 1998, 6, 663-674; d) C. Müller, D. Vos, P. Jutzi, J. Organomet. Chem. 2000, 600, 127-143; e) H. Butenschön, Chem. Rev. 2000, 100, 1527-1564; f) U. Siemeling, Chem. Rev. 2000, 100, 14951526; g) Y. Qian, J. Huang, M.D. Bala, B. Lian, H. Zhang, H. Zhang, Chem. Rev. 2003, 103, 2633-2690; h) M. Enders, R. W. Baker, Current Org. Chem. 2006, 10, 937 - 953; i) S.P. Downing, A.A. Danopoulos, Organometallics 2006, $25,1337-1340$.

2 (a) J. Okuda, in Metallocenes; A. Togni, R.L. Halterman, Eds.; WileyVCH: Weinheim, 1998, p 415-453; b) O. Daugulis, M. Brookhart, P. S. White Organometallics, 2003, 22, 4699-4704; c) A. Döhring, G. Göhre, P.W. Jolly, B. Kryger, J. Rust, G.P.J. Verhovnik, Organometallics 2000, 19 388-402.; (d) H. Zhang, J. Ma, Y. Qian, J. Huang, Organometallics 2004, 23, 5861-5868. e) M. Enders, P. Fernández, G. Ludwig, H. Pritzkow, Organometallics, 2001, 20, 5005-5007; f) S. Randoll, P.G. Jones, M. Tamm, Organometallics 2008, 27, 3232-3239; g) S. Derlin, W. Kaminsky, Macromolecules 2008, 41, 6280-6288.

3 a) J. Huang, T. Wu, Y. Qian, Chem. Commun. 2003, 2816-2817. b) P. J. W. Deckers, B. Hessen, J. H. Teuben, Angew. Chem., Int. Ed. 2001, 40, 2516-2519.

4 G. Kohl, R. Rudolph, H. Pritzkow, M. Enders, Organometallics 2005, 24, 4774-4781.

5 M.L. Buil, M. A. Esteruelas, A.M. Lopez, A.C. Mateo, E. Onate Organometallics 2007, 26, 554-565.

6 Many systems fall into this category. Often the $\mathrm{Cp}$ bound metal is already coordinatively saturated. The most prominent examples are donor functionalized ferrocenes. See for example: A. Togni in Metallocenes; A. Togni, R.L. Halterman, Eds.; Wiley-VCH: Weinheim, 1998; p 686-721 and ref. cited therein.

7 a) M.P. Thornberry, C. Slebodnick, P.A. Deck, F.R. Fronczek, Organometallics 2001, 20, 920-926; b) R.W. Baker, M.A. Foulkes, J.A Taylor, J. Chem. Soc., Perkin Trans. 1 1998, 1047-1058; c) C. Moberg, O. Wenneström, Act. Chem. Scand. 1971, 25, 2871-2878.

8 T. Suzuki, T. Tsuji, T. Okubo, A. Okada, Y. Obana, T. Fukushima, T Miyashi, Y. Yamashita, J. Org. Chem. 2001, 66, 8954-8960.

9 M. Enders, G. Kohl, H. Pritzkow, Organometallics 2004, 23, 3832-3839.

10 a) S. Barlow, D. O`Hare, Chem. Rev. 1997, 97, 637-670; b) A. Tárraga, P. Molina, D. Curiel, J.L. López, M.D. Velasco, Tetrahedron 1999, 55 , 14701-14718; c) E. Bunel, P. Campos, J. Ruz, L. Valle, I. Chadwick, M.S. Ana, G. Gonzalez, J.M. Manriquez, Organometallics 1988, 7, 474-476.

11 Z. Ziniuk, I. Goldberg, M. Kol, J. Organomet. Chem. 1997, 545, 441446.

12 a) N. W. Alcock, A. F. Hill, M. S. Roe, J. Chem. Soc. Dalton Trans. 1990, 1737-1740; b) M. Munakata, T. Kuroda-Sowa, M. Maekawa, M. Nakamura, S. Akiyama, S. Kitagawa, Inorg. Chem. 1994, 33, 1284.

13 P. Fernandez, H. Pritzkow, J.J. Carbo, P. Hofmann, M. Enders, Organometallics 2007, 26, 4401-4412.

14 a) G. N. La Mar, W. Horrocks, Jr., R. H. Holms, Eds., "NMR of Paramagnetic Molecules: Principles and Applications" Academic Press, NY, 1973; b) I. Bertini, C. Luchinat, G. Parigi, "Solution NMR of Paramagnetic Molecules”, Elsevier 2001; c) F. H. Köhler, “Magnetism: Molecules to Materials" Wiley-VCH Verlag GmbH, Weinheim, Germany, 2001, 379.

15 Gaussian 03, Revision B.03, M. J. Frisch et al. Gaussian, Inc., Pittsburgh PA, 2003.

16 K. H. Theopold, Eur. J. Inorg. Chem. 1998, 15-24.

17 M. J. Edelmann, J. M. Raimundo, N. F. Utesch, F. Diederich, C. Boudon, J.-P. Gisselbrecht, M. Gross, Hel. Chim. Acta. 2002, 85, 2195-2213.

18 a) R. Cramer, Inorg. Chem. 1962, 1, 722-723. b) R. Cramer, Inorg. Synth. 1990, 29, 86-88.

19R. Arnold, B.M. Foxman, M. Rosenblum, W.B. Euler, Organometallics 1988, 7, 1253-1259.

20 G. M. Sheldrick, SHELXS-97, University of Göttingen, Germany, 1997.

21 G. M. Sheldrick, Acta Cryst. 2008, A64, 112.
22 P. T. Beurskens, in: G. M. Sheldrick, C. Krüger, R. Goddard (eds.), Crystallographic Computing 3, Clarendon Press, Oxford, UK, 1985, p. 216; P. T. Beurskens, G. Beurskens, R. de Gelder, J. M. M. Smits, S. GarciaGranda, R. O. Gould, DIRDIF-2008, Radboud University Nijmegen, The Netherlands, 2008.

23 G. M. Sheldrick, SHELXL-97, University of Göttingen, 1997. 
Received: ((will be filled in by the editorial staff)) Published online: ((will be filled in by the editorial staff))

1

4

5

6

8

9

10

11

12

13

14

15

16

17

18

19

20

21

22

23

24

25

26

27

28

29

30

31

32

33

34

35

36

37

38

39

40

41

42

43

44

45

46

47

48

49

50

51

52

53

54

55

56

57

58

59

60 
5

6
7

8

9

10

11

12

13

14

15

16

17

18

19

20

21

23

24

25

26

27

29

30

31

32

33

34

35

36

37

38

39

40

41

42

43

44

45

46

47

48

49

50

51

52

53

54

55

56

57

58

59 


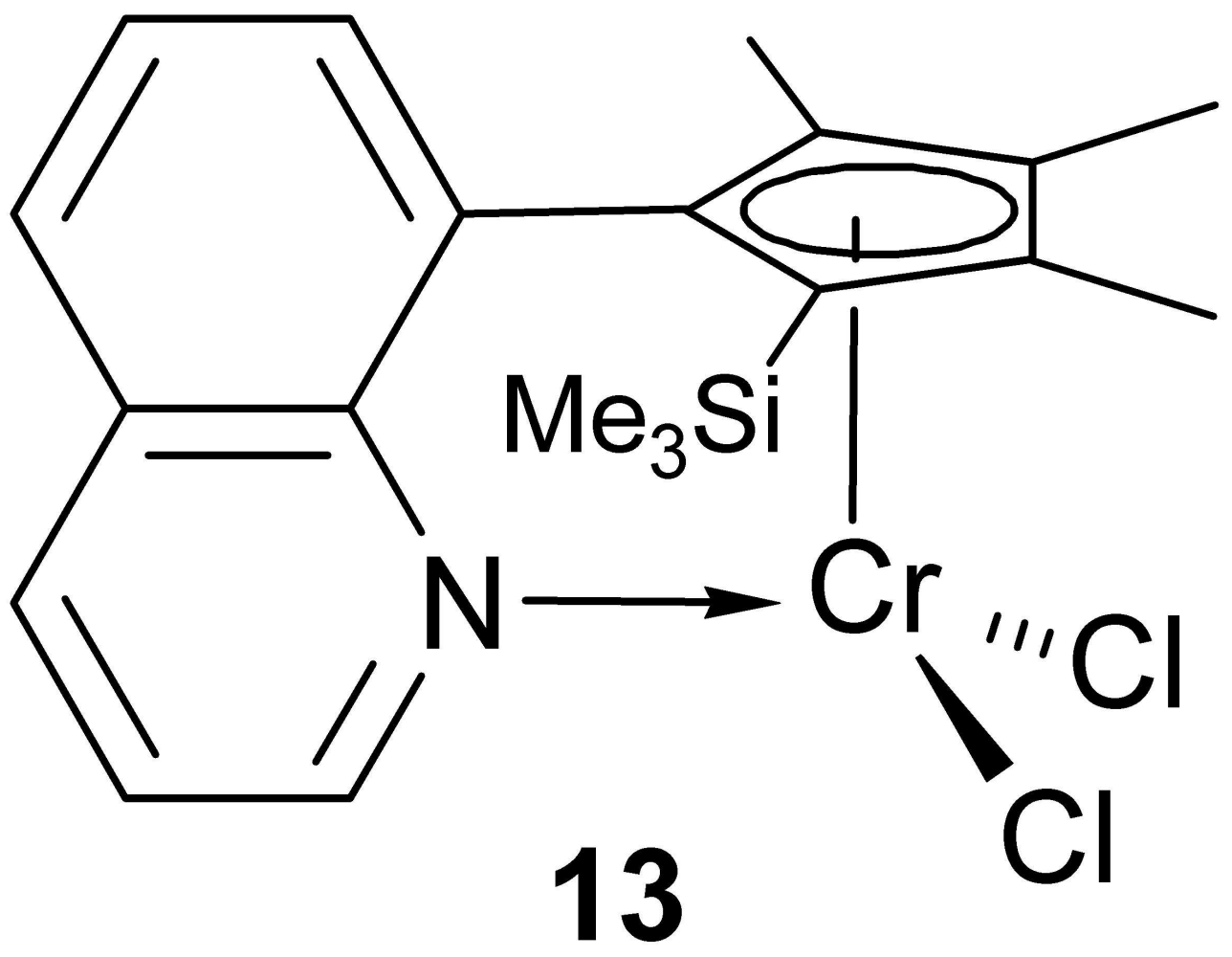

compound 13 without caption

$846 \times 660 \mathrm{~mm}(72 \times 72 \mathrm{DPI})$ 


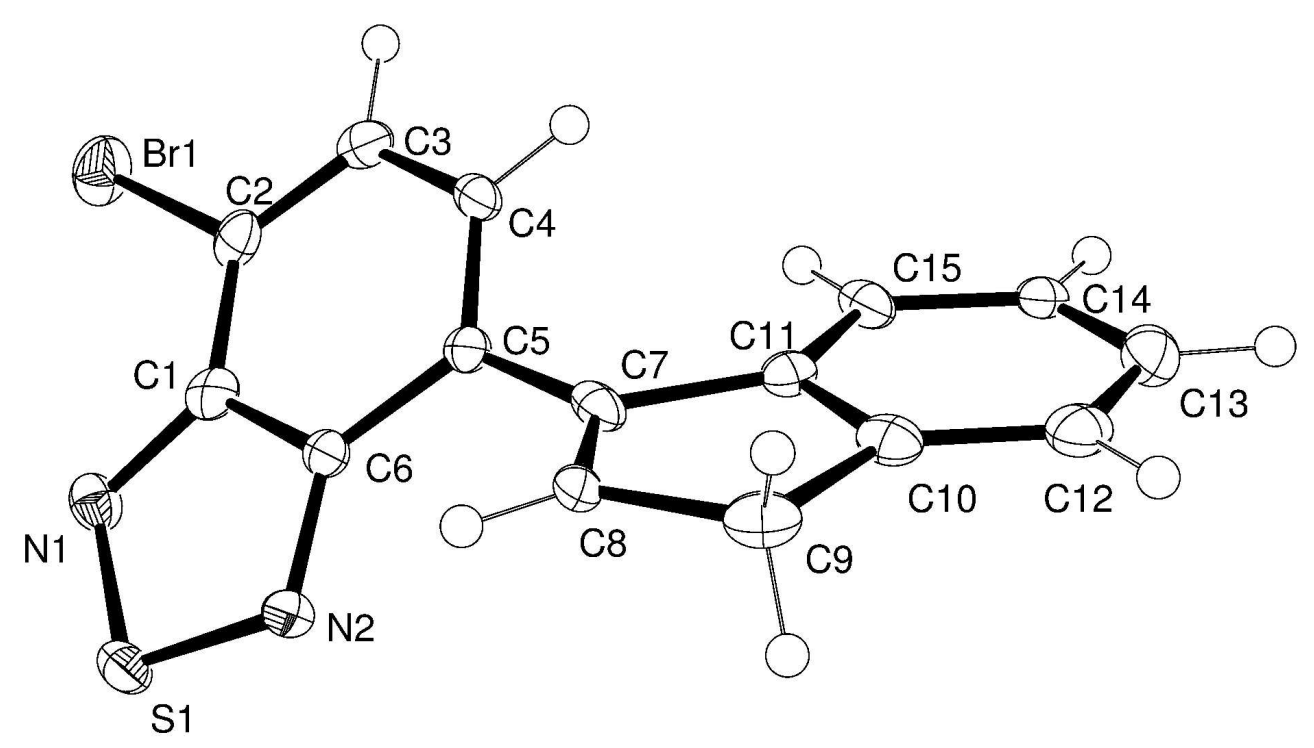

Figure 1

$241 \times 137 \mathrm{~mm}(600 \times 600$ DPI) 


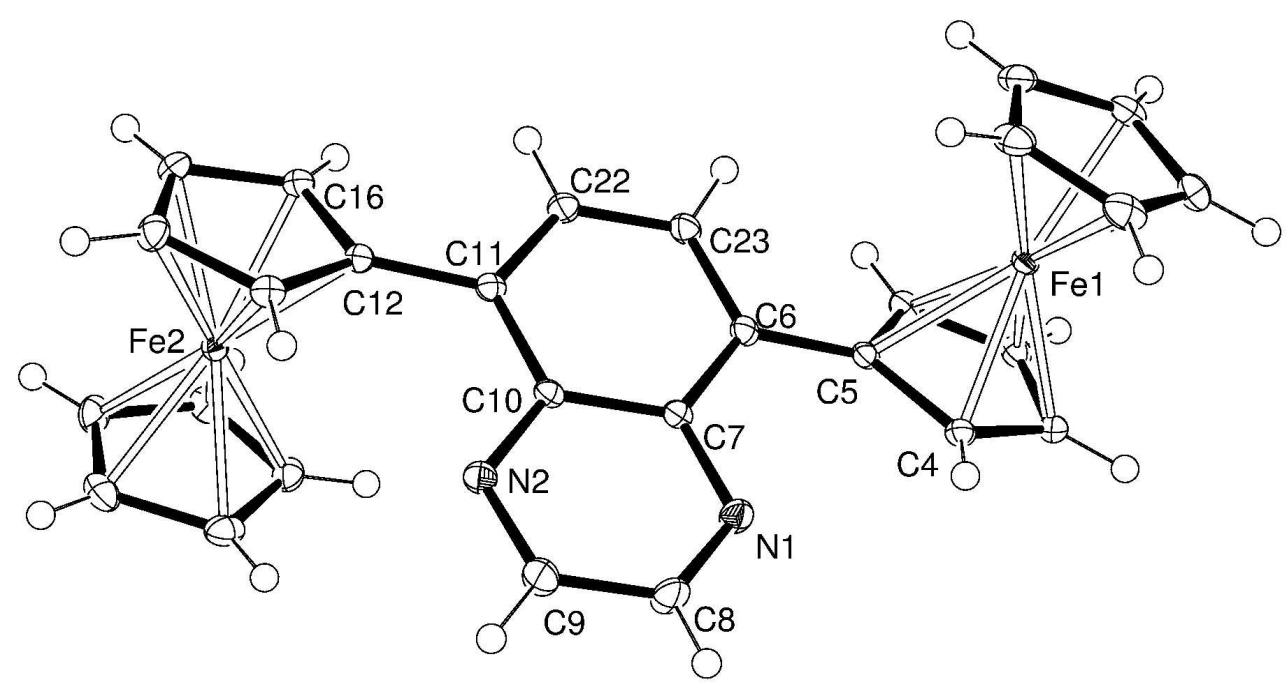

Figure 2

$236 \times 130 \mathrm{~mm}(600 \times 600 \mathrm{DPI})$ 


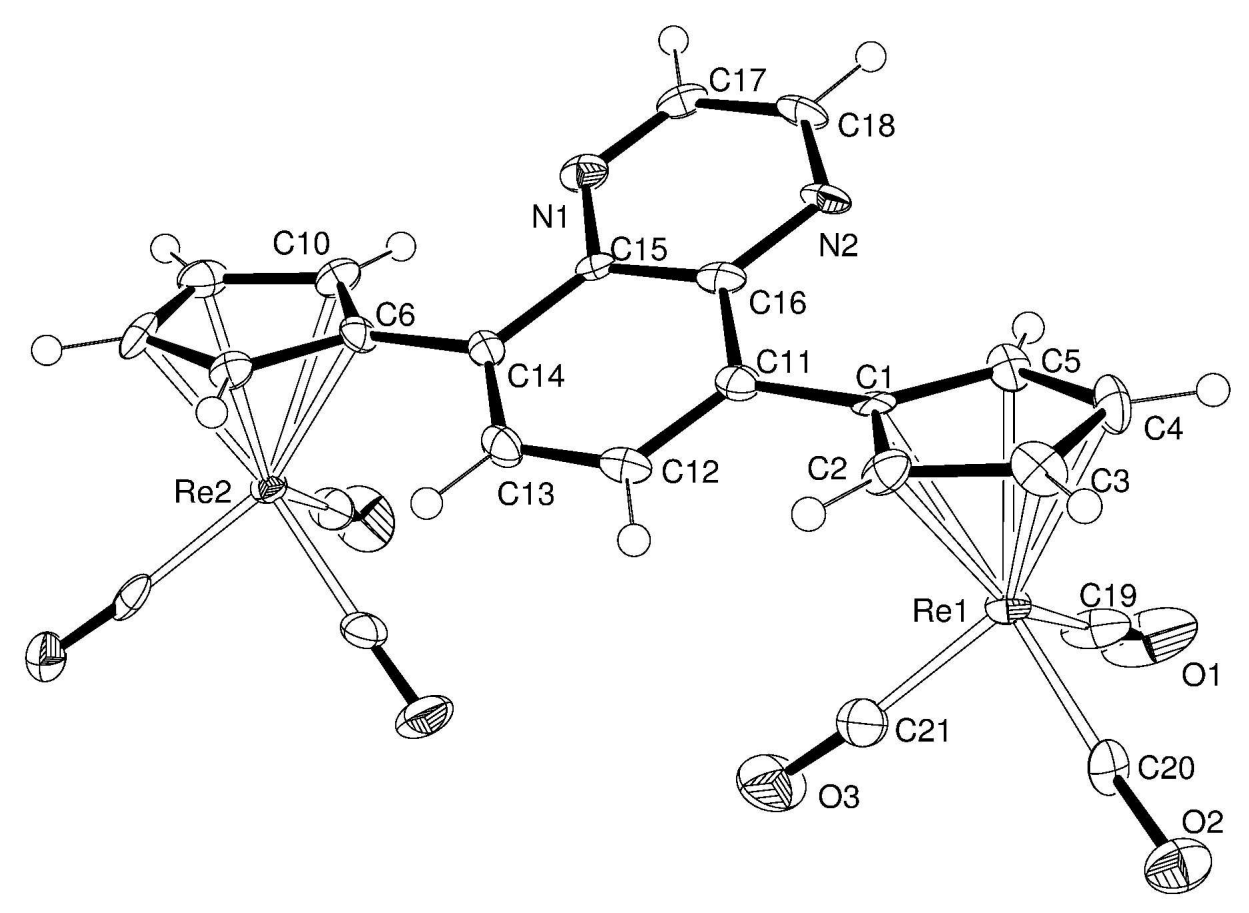

Figure 3

$248 \times 175 \mathrm{~mm}(600 \times 600 \mathrm{DPI})$ 


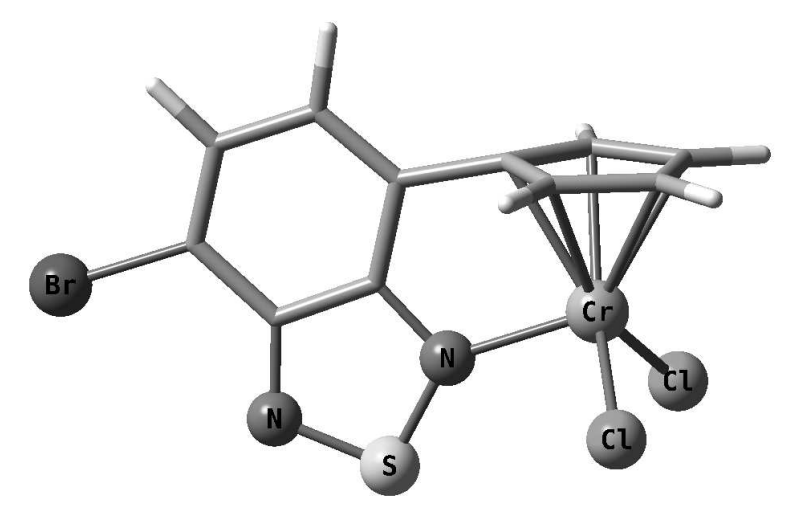

Figure 4

$1144 \times 871 \mathrm{~mm}(72 \times 72$ DPI $)$

Wiley-VCH 


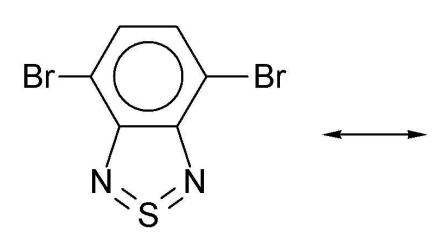

A

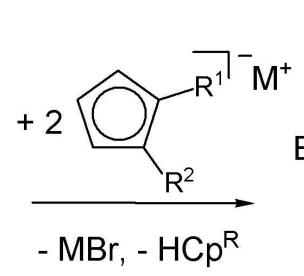<smiles></smiles>

$\mathrm{R}^{1} / \mathrm{R}^{2}=$ benzo: $1 \mathrm{Li}$ $\mathrm{R}^{1}=\mathrm{R}^{2}=\mathrm{H}: 2 \mathrm{Na}$ $\mathrm{R}^{1}=\mathrm{H}, \mathrm{R}^{2}=t-\mathrm{Bu}: 3 \mathrm{Li}$

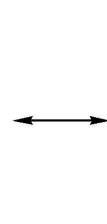<smiles>Brc1ccc(Br)c2nsnc12</smiles>

C

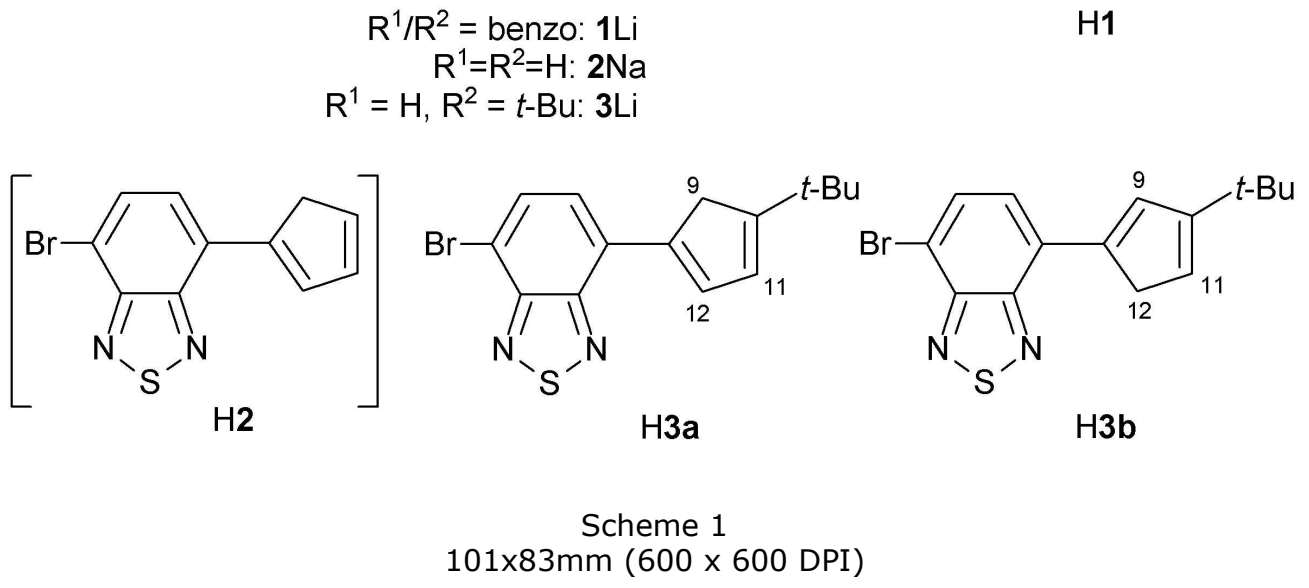
$101 \times 83 \mathrm{~mm}(600 \times 600$ DPI $)$ 


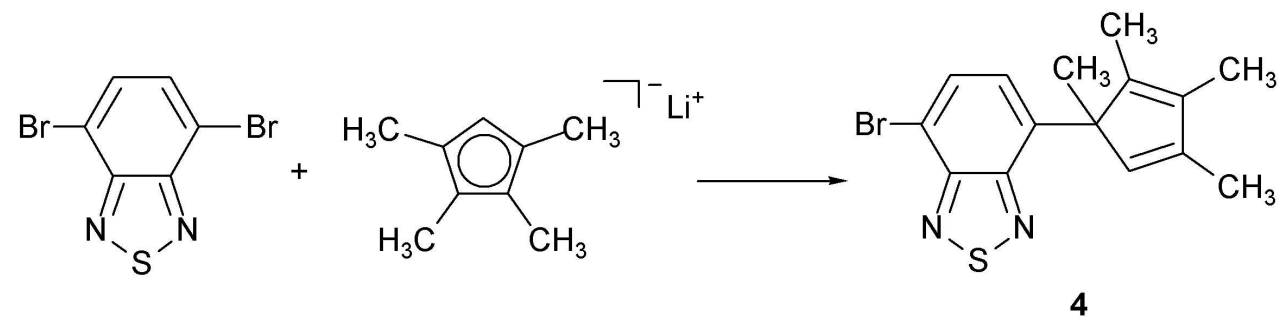

Scheme 2

$101 \times 26 \mathrm{~mm}(600 \times 600 \mathrm{DPI})$

20

21

22

23

24

25

26

27

28

29

30

31

32

33

34

35

36

37

38

39

40

41

42

43

44

45

46

47

48

49

50

51

52

53

54

55

56

57

58

59

60 

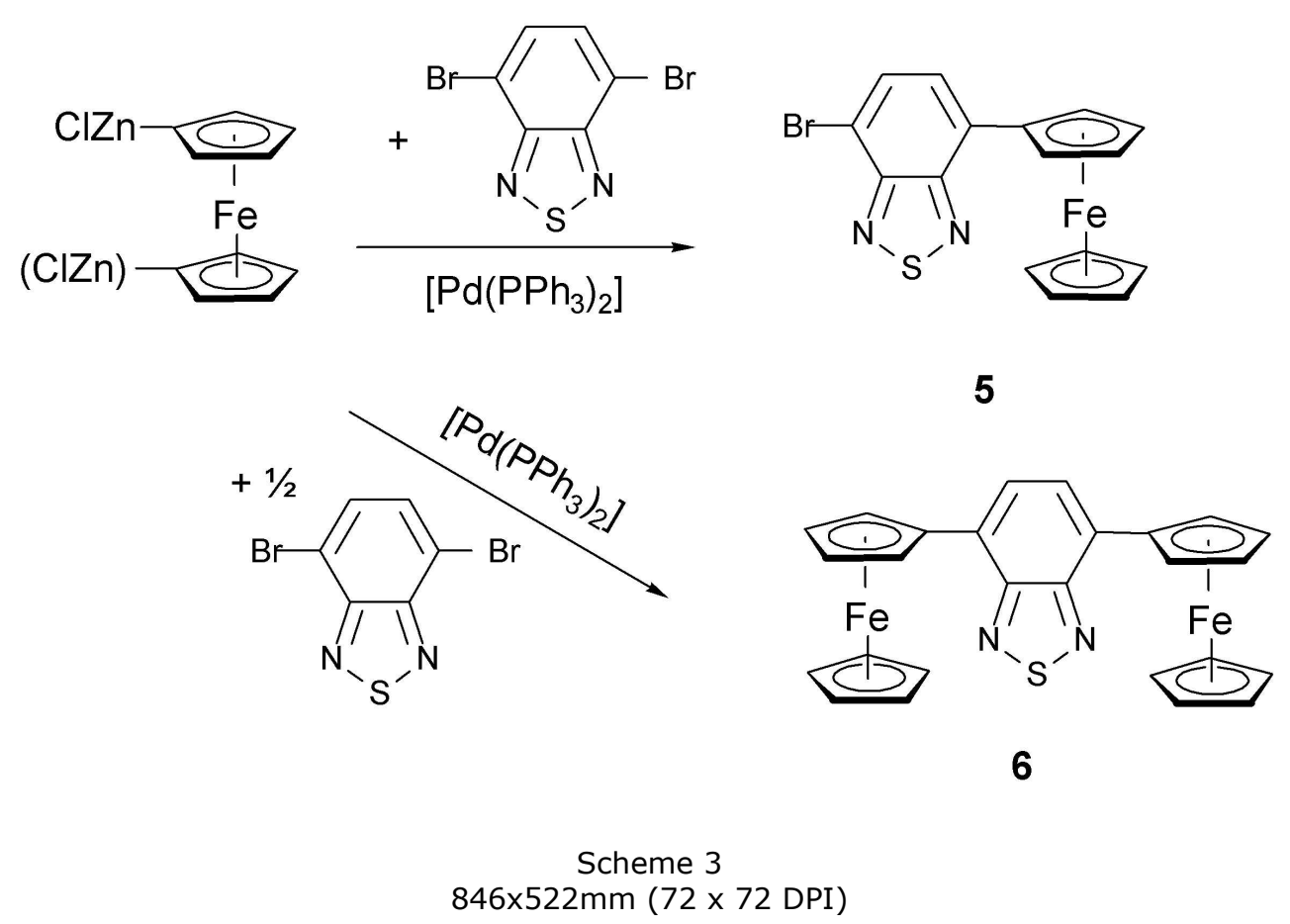


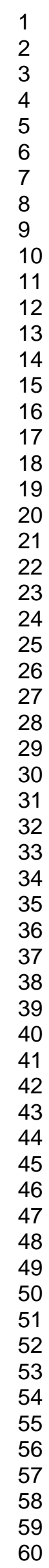
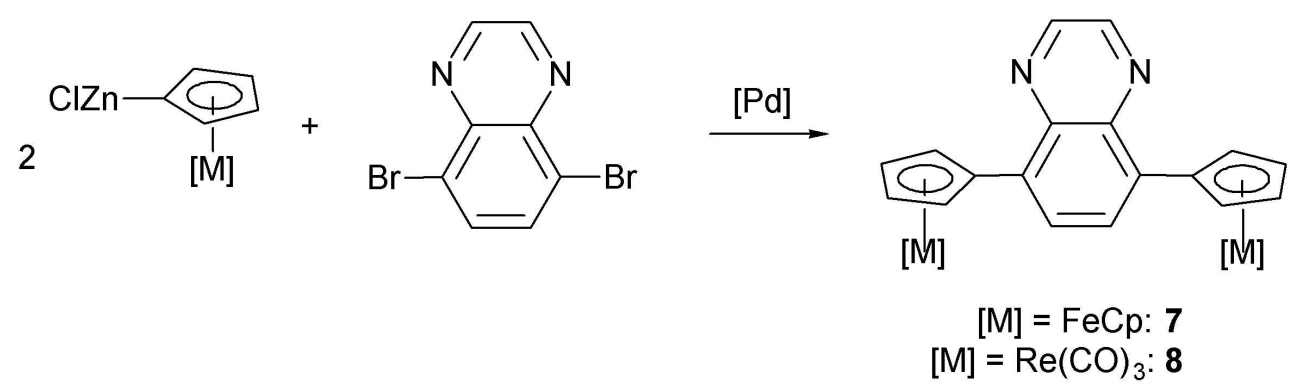

Scheme 4

$846 \times 252 \mathrm{~mm}(72 \times 72$ DPI $)$ 

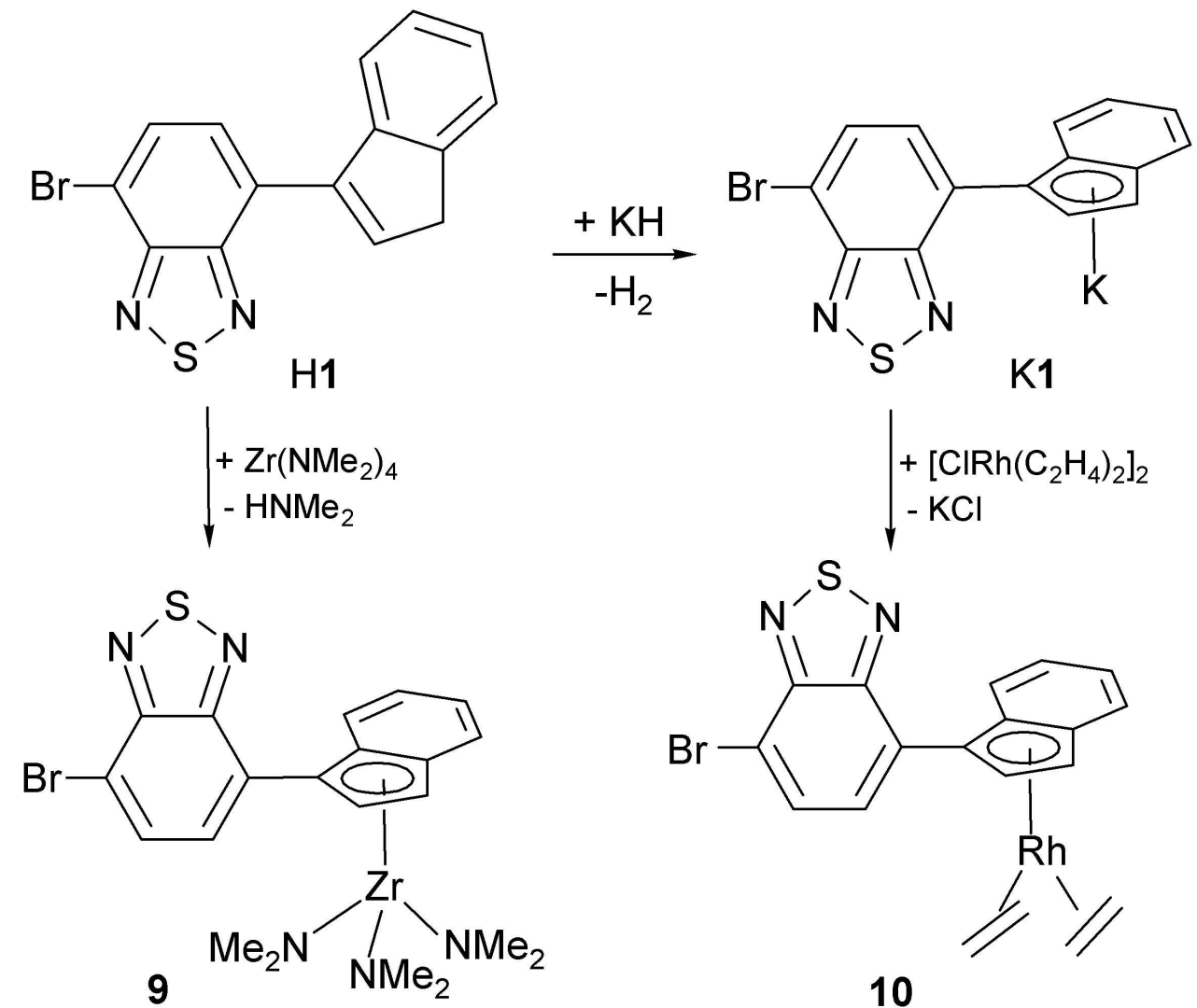

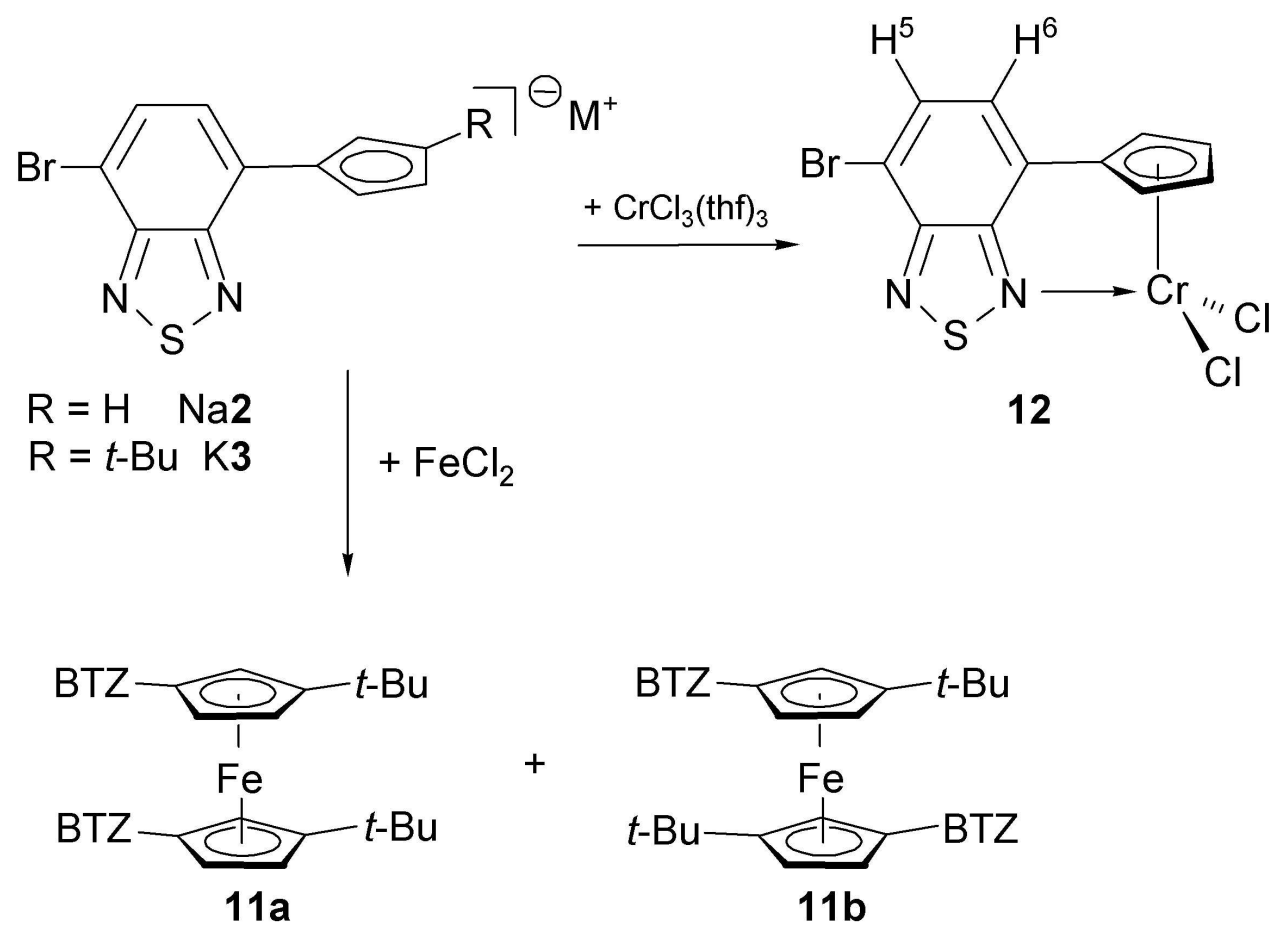

Scheme 6

$846 \times 609 \mathrm{~mm}$ ( $72 \times 72$ DPI) 